NBER WORKING PAPER SERIES

\title{
NO TAXATION WITHOUT INFORMATION: DETERRENCE AND SELF-ENFORCEMENT IN THE VALUE ADDED TAX^
}

\author{
Dina Pomeranz \\ Working Paper 19199 \\ http://www.nber.org/papers/w19199
NATIONAL BUREAU OF ECONOMIC RESEARCH
1050 Massachusetts Avenue
Cambridge, MA 02138
July 2013

I thank Alberto Alesina, Samuel Asher, Lorenzo Casaburi, Raj Chetty, David Cutler, Oeindrila Dube, Martin Feldstein, Brigham Frandsen, Edward Glaeser, Dominik Hangartner, Lakshmi Iyer, Kelsey Jack, Matthew Gentzkow, Louis Kaplow, Felipe Kast, Lawrence Katz, Henrik Kleven, Wojciech Kopczuk, Michael Kremer, Josh Lerner, Jeffrey Liebman, Stephan Litschig, Isaac Mbiti, Stephan Meier, Sendhil Mullainathan, Paul Niehaus, Suresh Naidu, Giacomo Ponzetto, Joel Slemrod, Matthew Weinzierl, Justin Wolfers, Danny Yagan, Tristan Zajonc and participants at various seminars and conferences for helpful comments and discussions. I am exceedingly grateful to the Chilean Tax Authority for outstanding collaboration and funding of the implementation and to the Swiss Study Foundation, the David Rockefeller Center for Latin American Studies, and the Project on Justice Welfare and Economics for research and travel grants that made this project possible. The views expressed herein are those of the author and do not necessarily reflect the views of the National Bureau of Economic Research.

NBER working papers are circulated for discussion and comment purposes. They have not been peerreviewed or been subject to the review by the NBER Board of Directors that accompanies official NBER publications.

(C) 2013 by Dina Pomeranz. All rights reserved. Short sections of text, not to exceed two paragraphs, may be quoted without explicit permission provided that full credit, including $\odot$ notice, is given to the source. 
No Taxation without Information: Deterrence and Self-Enforcement in the Value Added Tax^ Dina Pomeranz

NBER Working Paper No. 19199

July 2013

JEL No. H25,H26,O17,O23

\begin{abstract}
Tax evasion generates billions of dollars of losses in government revenue and creates large distortions, especially in developing countries. Claims that the VAT facilitates tax enforcement by generating paper trails on transactions between firms have contributed to widespread VAT adoption worldwide, but there is little empirical evidence about this mechanism. This paper analyzes the role of third party information for VAT enforcement through two randomized experiments among over 400,000 Chilean firms. Announcing additional monitoring has less impact on transactions that are subject to a paper trail, indicating the paper trail's preventive deterrence effect. Tax enforcement leads to strong spillovers up the VAT chain, increasing compliance by firms' suppliers. These findings confirm that when evasion is taken into account, significant differences emerge between otherwise equivalent forms of taxation.
\end{abstract}

\author{
Dina Pomeranz \\ Harvard Business School \\ Rock Center 213 \\ Soldiers Field \\ Boston, MA 02163 \\ and NBER \\ dpomeranz@hbs.edu
}




\section{Introduction}

A fundamental constraint for taxation is that governments need to be able to observe transactions in the economy in order to be able to impose a tax on them. A growing literature therefore argues that understanding information flows is central to effective taxation. When governments imperfectly observe transactions, important differences emerge between forms of taxation that are equivalent in standard models of taxation but differ in the information they generate for the government (Slemrod, 2008). ${ }^{1}$ Third-party reporting, verifiable paper trails, and whistle-blowers are thought to play an important role in facilitating tax enforcement (Kopczuk and Slemrod, 2006; Kleven et al., 2009, 2011; Kumler et al., 2012). The challenge of enforcing taxation is particularly severe in developing countries, where many transactions in the economy are not readily observable by the government, and it has been argued that these limited sources of information can explain some of the key differences in tax systems between developed and developing countries (Gordon and Li, 2009; Besley and Persson, 2012). ${ }^{2}$

The Value Added Tax (VAT) is a stark example of a tax believed to facilitate enforcement through a built-in incentive structure that generates a third-party reported paper trail on transactions between firms, which makes it harder to hide the transaction from the government (e.g. Tait, 1972; Burgess and Stern, 1993; Agha and Haughton, 1996; Kopczuk and Slemrod, 2006). This belief has contributed to one of the most significant developments in tax policy of recent decades (Keen and Lockwood, 2010): a striking increase in VAT adoption from 47 countries in 1990 to over 140 today (Bird and Gendron, 2007). There is, however, surprisingly little evidence evaluating these self-enforcing properties of the VAT.

This paper investigates the role of third-party reported paper trails for tax enforcement, and tests for the self-enforcing properties in the VAT through two randomized field experiments with over 445,000 firms in Chile. A first experiment, the large-scale "Letter Message Experiment," evaluates the effects of the VAT paper trail across the entire economy in a fully developed VAT system. It investigates whether the presence of the VAT paper trail lowers the tax payment response to an increase in the perceived audit probability of randomly chosen firms. This would suggest that the paper trail has a preventive deterrence

\footnotetext{
${ }^{1}$ Information constraints have been a key feature of models in the optimal taxation literature as well. While ability is not observable in these models, most transactions in the economy are typically assumed to be observable.

${ }^{2}$ Tax evasion is a fundamental challenge for developing countries, where on average, the informal sector represents about $40 \%$ of GDP, ranging up to $70 \%$ (Schneider et al., 2010). High evasion rates can not only severely restrict funding for basic public infrastructure, they can also lead to significant distortions in the economy. Even in the US, overall tax evasion is estimated to be around 16\% (Internal Revenue Service, 2008), a loss similar in size to the entire corporate income tax.
} 
effect on evasion. Since a paper trail facilitates detection of evasion during the audit, one would expect firms to respond more to an increase in the audit probability where a paper trail is present, if evasion levels are equal across transactions. Observing that a given firm responds less on its transactions that are covered by a paper trail therefore suggests that the preventive deterrence effect of the paper trail was strong enough to reduce evasion to the point where an increase in the audit probability has a smaller effect. The experiment exploits the fact that the incentive structure built into the VAT system, which generates the paper trail, breaks down at the final production stage, where sales are made to consumers, rather than other firms: while it is in firms' interest to ask suppliers for receipts in order to deduct input costs from their VAT bill, consumers have no incentive to do so.

The Chilean Tax Authority sent letters indicating an increased audit probability to over 100 thousand randomly selected firms. While the letters generate an immediate and strong increase in VAT payments, this effect is much weaker on transactions between firms, where the paper trail is present, than on sales to final consumers, where there is no VAT paper trail. This holds true not only when comparing between firms with different shares of final sales, but also when comparing the response of different types of transactions within a given firm. Consistent with a model by Kleven et al. (2009) about the impact of firm size on evasion, I also find that small firms respond more to the deterrence message. There is suggestive evidence that a substantial fraction of the higher response in smaller firms may be driven by their higher propensity to sell at the retail level, where the VAT paper trail is absent. ${ }^{3}$

Conceptually, this type of intervention represents an indirect use of randomized experiments, as defined by Khwaja and Mian (2011). It allows studying an existing policy at large scale, even if the policy itself cannot be randomized. The idea is to test whether randomly induced variation of another factor that interacts with the policy (in our case the perceived audit probability) generates the response that would be predicted based on the underlying mechanism if the policy is effective. The two experiments provide both types of interventions in the classification of Ludwig et al. (2011). The Letter Message Experiment is an (indirect) policy evaluation, aimed at testing whether the policy works on a nation-wide level, while the second experiment, the "Spillover Experiment," is a mechanism experiment, aimed at showing the underlying mechanism that leads the policy to be effective.

The Spillover Experiment was designed to find direct evidence for the self-enforcing mech-

\footnotetext{
${ }^{3}$ In order to test whether the impact of the letter really stems from deterrence, I also compare its effect to both a motivational letter that appeals to tax morale and social norms, and a placebo letter that contains information that is irrelevant for tax compliance. The methodology of analyzing the impact of different letter messages on tax payments was first developed by Slemrod et al. (2001), and has recently been employed by Engstrom and Hesselius (2007) and Fellner et al. (Forthcoming), shedding light on the impact of deterrence and motivational appeals on tax payments by individuals in developed countries.
} 
anism that underlies the findings of the Letter Message Experiment. It examines the transmission of tax enforcement through the VAT paper trail up the production chain. The idea is to jumpstart the effect in a sample where it is not currently well enforced, by injecting deterrence into the system and observing how it promulgates along the paper trail and up the production chain. Half of a selected sample of firms suspected of tax evasion was randomly selected to receive an announcement of an upcoming audit. The whole sample was later summoned for an audit, and for the 1,527 firms that the tax authority was able to audit, information about their pre-treatment trading partners was collected. ${ }^{4}$ The randomly administered audit announcement leads to strong spillover effects that increase VAT payments by the suppliers of the treated firms. In line with the asymmetric incentives between clients and suppliers in the self-enforcing mechanism of the VAT, tax payments of client firms do not increase.

Taken together, the two experiments show that for a given firm, the VAT paper trail acts as a substitute to the firm's own audit probability, and globally the paper trail acts as a complement to the audit probability, since its effectiveness gets multiplied through the spillover effects. This represents the first micro-empirical evidence for the self-enforcing properties of the VAT. Previous evidence has been limited to cross-country comparisons, investigating whether countries that adopt a VAT subsequently raise more taxes (e.g. Nellor, 1987; Ebrill, 2001).

These findings provide the first evidence of how tax enforcement generates spillovers through firms' trading networks, and together with Rincke and Traxler (2011), they represent one of the first documentations of spillovers in tax enforcement overall. The results imply that when choosing an optimal audit strategy, a tax authority may not only want to consider the expected deterrence effect on the audited firm, but also the multiplier effect through the firm's trading network.

This paper also provides evidence for a larger, mostly theoretical literature on the importance of information and third-party reporting for effective taxation, particularly in developing countries (e.g. Kopczuk and Slemrod, 2006; Gordon and Li, 2009; Kleven et al., 2009). Because evasion is by its nature difficult to detect, and micro-level tax data is highly confidential, there has been a dearth of micro-empirical evidence (Slemrod and Yitzhaki, 2002). One notable exception in this area is an intervention conducted concurrently to this field experiment by Kleven et al. (2011), who analyze the individual income tax in Denmark and formalize the distinction between third-party and self-reported income. They find that evasion is generally low, except for the small fraction of income for which the government does not already possess third party-reported information. These results confirm related findings

\footnotetext{
${ }^{4}$ For a discussion of attrition at the auditing stage, see the implementation section below.
} 
for the income tax on a more aggregate level by the US Taxpayer Compliance Measurement Program (TCMP) (Internal Revenue Service, 1996, 2006). ${ }^{5}$

The paper extends the findings of this literature in several ways. First, it looks at tax compliance by firms, rather than by individuals. Raising and enforcing tax payments from firms strongly reduces the number of agents the tax authorities must oversee (Kopczuk and Slemrod, 2006), and thus may be a more feasible approach for developing countries to increase tax revenue. Firms can play an important role of aggregators of information that facilitates tax enforcement. Second, it analyzes tax compliance in a developing country context. Evasion rates are much higher in poorer countries, and while there is a growing empirical literature investigating taxation in such contexts (e.g. Engel et al., 1998; Fisman and Wei, 2004; Olken and Singhal, 2011; Carrillo et al., 2012; Kleven and Waseem, 2012; Kumler et al., 2012), there is still very little micro-empirical evidence.

Third, the findings speak to the interplay of information with deterrence in tax enforcement. In the sample of the Spillover Experiment, prior to the audit announcement, selfenforcement was incomplete at best. The deterrence effect from the audit announcement was necessary to trigger the effectiveness of the paper trail, showing that it is the interaction of information with deterrence that leads to effective tax enforcement. Finally, and particularly relevant for developing countries, the paper finds that third-party records strongly affect tax compliance even in a context where they are not automatically accessible to the tax authority. For most transactions in Chile, as in most developing countries, records are kept in handwritten books. The tax authority can verify them during audits, but in contrast to many developed countries, these records are not available in electronic form for automatic cross-checks.

The remainder of this paper is structured as follows: Section 2 provides background on the VAT in Chile and on the mechanism of the self-enforcement hypothesis of the VAT, Section 3 describes study design, data and estimation strategy, and Section 4 shows the results of the Letter Message Experiment and the Spillover Experiment in turn. Section 5 concludes.

\footnotetext{
${ }^{5}$ Alm et al. (2007) study a related question in a lab setting, by experimentally varying the portion of an individual's income that is subject to third-party reporting, and find that cheating increases as individuals earn larger shares of income that are not perfectly detectable.
} 


\section{Context}

\subsection{Background on the VAT and its Use in Chile}

As its name suggests, the Value Added Tax is paid on the value added at each production stage: firms pay VAT on the difference between total sales and total input costs. The overall tax base - total value added in the production chain - is therefore equivalent to that of a sales tax, which is paid on the entire final value at the retail stage. ${ }^{6}$ The main difference between a VAT and a retail sales tax lies in the way it is collected and in who remits the tax to the government, a difference that is irrelevant in most standard tax models, but is thought to have significant implications when taking tax administration and tax evasion into account (Slemrod, 2008).

To comply with VAT obligations, firms have to maintain books of sales and purchases with corresponding original receipts of transactions, in order to document their declared amounts of their "tax debit" (sales and other sources of revenue) and "tax credit" (input costs). ${ }^{7}$ The book of purchases therefore contains documentation about the sales of firms' suppliers. This leads to the third-party paper trail along the production chain (henceforth referred to as "paper trail"). The client firm maintains a record about the sales of the supplier, which allows for the possibility that the tax authority can cross-check the two firms' records against each other. In Chile, as in many other countries, most firms do not have to submit this information to the tax authority. Only very large firms and a small number of firms who choose to use an online filing system do so. For all other firms, this information can potentially be accessed by the tax authority through an audit, but not as a matter of routine. Understanding whether the paper trail can have a preventive deterrence effect even in these settings is of particular interest. This is also the reason that the tax authority does not generally know which firms deal with which other firms. For this reason, the spillover experiment was designed to collect information about firms' trading partners up and down the production chain.

A large majority of countries around the world currently have a VAT, and for many developing countries it represents the largest source of tax revenue. In Chile, the VAT accounts for about half of tax revenues (Servicio de Impuestos Internos, 2010a). Chile has a single 19\% VAT rate on sale of goods and services across all types of products, which is paid

\footnotetext{
${ }^{6}$ This equivalence holds when the VAT has a uniform rate and no exemptions.

${ }^{7}$ This collection method is commonly known as the "credit-invoice method". The vast majority of countries with a VAT currently use the credit-invoice method with a few exceptions such as Japan that uses the subtraction method (Grinberg, 2010).
} 
monthly. ${ }^{8}$ Only very few industries are exempt, and there is no lower threshold, firms of all sizes are subject to the VAT. ${ }^{9}$ This context allows for analysis of the VAT across a large set of different types of firms, without the interference of confounding institutional factors such as industry-specific exemptions or varying taxation rates. Official estimates of VAT evasion in Chile, based on the comparison of collected VAT to aggregate consumption data from the central bank, have ranged between $27 \%$ and $12 \%$ since 1990, with significant fluctuations from one year to the next (Servicio de Impuestos Internos, 2010b). ${ }^{10}$

\subsection{Mechanism of the "Self-Enforcing" Properties of the VAT}

The "self-enforcement"-hypothesis in the VAT is based on the idea that firms have an incentive to ask their suppliers for receipts because they can deduct input costs from their VAT bill (Agha and Haughton, 1996). This incentive builds the creation of paper trails directly into the tax structure. Since the amounts are recorded in two sets of books, the risk of cross-checks is thought to deter firms from reporting differing amounts (Bird and Gendron, 2007). In this way, the buyer acts as the third-party, recording a transaction, which creates a liability for the supplier. An important feature of this mechanism is that the two sides of a transaction in inter-business trade have opposing incentives: the buyer benefits from overstating the input cost, while the seller benefits from understating the sale. In the middle of the VAT chain, there is therefore no scope for gains from collusion between the two parties. This mechanism breaks down at the final production stage, with sales to the final consumer, who has no incentive to ask for a receipt. There is therefore no "self-enforcing" effect for final transactions. ${ }^{11}$

There are several reasons why this self-enforcing mechanism might not work in practice. First, as mentioned above, most firms do not have to report this third-party information

\footnotetext{
${ }^{8}$ If the tax credit is greater than the debit for a given month, the excess can be carried over to the following month and used as a VAT credit (Servicio de Impuestos Internos, 2011).

${ }^{9}$ Only the following entities are VAT exempt: news organizations, transportation, education, public universities and hospitals, the central bank, the social security administration, the ministry of national defense, the national postal services, and the public lottery. As is usual for a VAT, exports are excluded, and exporters are reimbursed for the VAT cost embedded in the purchase price of their inputs.

${ }^{10}$ To prevent fraudulent production of fake input receipts from non-existing firms or duplications, all receipts used for VAT purposes have to be pre-approved and stamped in the offices of the Chilean tax authority. The tax authority uses the part of the cross-checkable information that is electronically on file to calculate whether tax declarations display any discrepancies. For the largest discrepancies, letters are sent informing firms of the discrepancy, and requiring them to explain or correct the situation. Tax officials regularly visit retail stores to check that the books are kept in order and correct receipts are used, however, typically no cross-checks or audits ensue from these visits, unless there is suspicion of grave infraction.

${ }^{11}$ For this reason, several countries have tried to increase the incentive for the final consumer, by introducing such measures as imposing fines for consumers who do not ask for a receipt, organizing lotteries with consumer receipt, allowing consumers to deduct a fraction of their VAT payments from their income tax, etc.
} 
directly to the government. The self-enforcing mechanism therefore depends on the deterrence effect of a cross-check conducted during a possible audit. The word "self-enforcement" is therefore misleading, since it can be expected to work only in interaction with credible deterrence on part of the tax authority. Second, since the mechanism breaks down at the final stage, it can potentially unravel from the bottom, if collusion builds up all the way from the final stage.

If the mechanism works, we would expect to see a preventive deterrence effect on transactions covered by the paper trail. This will affect how firms respond to an increase in the audit probability in the following way. The information contained in the paper trail facilitates detection of evasion during an audit. At a given level of evasion, one would therefore expect firms to respond more to an increased audit risk on transactions where a paper trail is present. The anticipation of this ease of detection can create a preventive deterrence effect, which reduces evasions ex-ante on transactions with a paper trail. If this deterrence effect is strong enough, it may reduce evasion to the point where an increase in the audit probability has a smaller effect on transactions covered by a paper trail (as there is less evasion on these transactions to begin with). At that point, the paper trail and the audit probability will interact in a substitutive way. Observing firms responding less on transactions with a paper trail therefore suggests that ex-ante evasion was lower on these transactions. The Letter Message Experiment tests whether this is the case. ${ }^{12}$

We can distinguish two forms of VAT evasion on inter-firm transactions. Through "Omission" a transaction is completely omitted from the books of both the seller and the buyer firm. This requires collusion, and as discussed above only reduces overall VAT payments if it is carried through all the way to the end of the production chain. "Discrepancies", represents evasion where a paper trail is created, but with discrepancies in the amounts that the buyer and seller report for the transaction. ${ }^{13}$ This type of evasion is based on the hope that the tax authority will not cross-check the records.

The Spillover Experiment complements the findings of the Letter Message Experiment by showing the mechanism by which the preventive deterrence effect on inter-firm transactions discussed above comes about. It analyzes the spillover effects of randomly generated audit pre-announcements on firms' trading partners. These spillover effects can operate through a reduction of both types of evasion on inter-firm evasion described above.

\section{[Table 1]}

\footnotetext{
${ }^{12}$ As discussed in more detail in the results section, the necessary assumption is that a lower response is not driven by other differences within firms for the type of transactions covered by a paper trail.

${ }^{13}$ In order to reduce tax liability, the seller will tend to understate the value of a transaction, while the buyer will tend to inflate it.
} 
In the case of omission, an increase in the audit probability of a trading partner increases the likelihood that this partner will insist that the transaction be "on the books." Hence, the audit pre-announcement can generate a paper trail. As illustrated in Table 1, this has asymmetric effects depending on whether a firm is a supplier or a client of the treated firm (i.e. of the firm that receives the pre-announcement). If the treated firm starts demanding a receipt, this will lead to an increase in suppliers' declared sales and therefore in suppliers' tax liability. For client firms, on the contrary, it will lead to an increase in declarable input costs, thereby lowering their tax liability. In the case of discrepancies, the spillover effects are symmetric for both suppliers and clients. The increased risk of cross-checks will lead all firms to revise their declared transactions in the direction of the actual value, increasing their tax liabilities.

Taking both types of evasion together, the effect of an increase in the audit probability on reported tax liability is unambiguously positive in the case of the suppliers, while in the case of clients, it is ambiguous depending on which type of inter-firm evasion dominates. The Spillover Experiment tests whether increasing a firm's audit probability indeed increases VAT payments by its trading partners, and whether this effect is asymmetrically concentrated on its suppliers.

\section{Study Design, Data and Empirical Specification}

\subsection{Study Design: Letter Message Experiment}

Both randomized field studies analyzed in this paper were conducted in collaboration with the Chilean Tax Authority ("Servicio de Impuestos Internos"). Research design diagrams for both experiments can be found in Figure A8 of the Appendix. The goal of the "Letter Message Experiment" is to evaluate the effectiveness of the VAT paper trail across the entire economy in a fully developed, well-functioning VAT system. Through letters sent by the tax authority, we vary the perceived audit probability of randomly chosen firms. The goal is to test for differential responses by whether or not transactions are covered by the VAT paper trail, i.e. whether the transactions are between other firms or to the final consumers. As discussed in Section 2, if we find that transactions that are subject to a paper trail respond less to an increase in the perceived audit probability, this indicates that the paper trail had a preventive deterrence effect prior to the intervention.

The main intervention consists of a letter containing a message of deterrence sent to 102,000 randomly selected firms in a stratified sample among most firms in the country. The letter is aimed at increasing the perceived audit probability by informing the firm that it has 
been randomly chosen for an analysis and that if any irregularities are detected, it may be audited (see Appendix A for the full text of all letters). This intervention did not affect the actual audit probability. Formally, the content of the message was nevertheless factually true - as certified after careful consideration by the tax authority's legal department - since the tax authority routinely analyses all firms, and firms may always be audited if irregularities are detected. ${ }^{14}$ The impact of the letter is measured by comparing the VAT payments of recipient firms to payments by the 306,600 firms randomly selected not to receive any letter.

The goal of the Letter Message Experiment is, however, not to measure the overall effect of the letter on firm compliance. The intention is to shed light on the effectiveness of the paper trail by analyzing how it interacts with the expected audit probability. This is achieved by comparing the responsiveness of line-items in the VAT declaration that are covered by the paper trail, i.e. transactions between two firms - to line items that are not - i.e. sales to final consumers. We can do this both across firms with different shares of their sales going to final consumers, and within firms by comparing the responsiveness of different line-items to each other. The latter allows holding constant any difference that may exist across firms with different shares of final sales, such as firm size, risk aversion, ease of hiding evasion etc.

Finally, the Letter Message Experiment also allows comparing the effect across different types of firms. ${ }^{15}$ In particular, I can test predictions about firm size. Kleven et al. (2009), for example, posit that large firms evade fewer taxes, since firms with more employees run a higher risk that a whistle-blower among their employees informs the government about unreported transactions. The employees in this case function as potential third-party reporters. We might therefore expect that firm size, similarly to the VAT paper trail, has a preventive deterrence effect that leads to a lower response to an increase in the audit probability. At the same time, smaller firms also tend to have a larger share of sales going to final consumers. Controlling for both firm size and share of final sales, we can get a sense of how much of the differential response by size may be driven by the degree of retail sales. ${ }^{16}$

\footnotetext{
${ }^{14}$ It is important to note that even though used surprisingly frequently in practice, sending out deterrence letters which are not backed up by a corresponding increase in the actual audit probability is not a policy that seems sustainable in the long-run. As a tool of analysis, it can be used to study differential responses by line item or type of tax payer, both for academic research or to optimize audit strategies (see Marshall and Pomeranz, 2011). However, ideally, tax authorities or other enforcement agencies using it should combine it with real changes in audit policy, particularly if repeated regularly, since it could otherwise start undermining the agency's credibility. Nevertheless, the strong response to the second wave of this experiment suggests that the deterrence letters do not lose their power very quickly.

${ }^{15}$ The Letter Message Experiment was also used to analyze other firm characteristics not reported in this paper, which are of interest to the tax authority, such as firm age, region, industry, etc. Based on the analysis of what type of firms are more likely to respond, we developed an instrument to optimize audit strategies for the Chilean Tax Authority (see Marshall and Pomeranz, 2011).

${ }^{16}$ However, it is important to keep in mind that such cross-firm comparisons have to be interpreted with caution, since in contrast to the within-firm estimates used to study the paper trail, other unobserved firm
} 
In order to test whether the impact of the letter really stems from deterrence, two additional letters, sent to a sample of about 18,500 each, were included in the study: a tax morale letter aimed at affecting perceived social norms and a "placebo" letter to test whether the simple fact of receiving mail from the tax authority was driving the impact. The placebo letter simply informs firms about some new features on the tax authority's website. The tax morale letter contains a message aimed at increasing the perceived social norm of tax compliance. ${ }^{17}$

\subsection{Study Design: Spillover Experiment}

While the Letter Message Experiment studies whether overall for representative firms, the paper trail interacts in a substitutive way with the audit probability, the Spillover Experiment is designed to show the underlying self-enforcing mechanisms in action. It analyzes whether, as predicted by the self-enforcement hypothesis, increased tax enforcement on one firm generates spillovers to its trading partners up the VAT chain. In order to analyze how the self-enforcing mechanism gets triggered by injecting deterrence into the system, the Spillover Experiment focuses on a set of firms where compliance is ex-ante expected to be low.

The intervention of the Spillover Experiment is as follows. 5,600 firms were scheduled for an audit by the tax authority. Half of them were randomly selected to receive a preannouncement for this audit (see Appendix Figure A4). The other half did not receive any message from the tax authority. Half a year later, the tax authority started summoning all firms in the sample to appear at the tax office for an audit. Since the tax authority does not have information on which firms trade with which, information about trading partners was collected during the audits. For the firms the tax authority was able to audit, ${ }^{18}$ auditors recorded information about the trading partners from the transaction records in the firms' books of sales and purchases for the three months prior to the mailing of the pre-announcement. This made it possible to identify the firms' main suppliers and clients in a period not yet affected by the treatment.

Based on this information, the spillover effects of the audit pre-announcement on suppliers and clients of the treated firms can be measured by comparing their declared VAT to the declared VAT of suppliers and clients of the control firms, before and after the time when the

characteristics may affect the differential estimates.

${ }^{17}$ Motivational messages have been found to increase voluntary cooperation in some instances. For example, Dal Bó and Dal Bó (2009) find that moral suasion can increase cooperation in the lab, especially when coupled with deterrence, and Fellner et al. (Forthcoming) find that social norm letters increase compliance with broadcast tax obligations for those who live in regions with generally low compliance.

${ }^{18}$ For a discussion of attrition at the auditing stage see Section 3.3 below. 
audit pre-announcement was sent out. Finding that trading partners of treated firms increase their declared VAT compared to trading partners of control firms indicates a spillover effect, since whether or not ones' trading partner was treated is randomly assigned.

\subsection{Implementation and Data}

The universe of firms considered in this study consists of almost all firms in Chile that were operating in June 2008 and had declared a positive amount of VAT for at least one month between July 2007 and June 2008. A subsample of 5,600 firms was selected for the Spillover Experiment, the remainder is in the Deterrence Letter Experiment. The only firms that were excluded from the study were very large firms and firms in the Letter Message Experiment that had undeliverable addresses and could therefore not receive a letter. The main data used in the study consists of information from the monthly VAT declarations by firms, starting in January 2008. In addition, I merge this data with some firm characteristics such as firm size, number of employees, industry, etc.

\section{Implementation and Summary Statistics: Letter Message Experiment}

Most letters in the Letter Message Experiment were sent in early December 2008, affecting tax declarations starting in November 2008, which are due in the following month. A smaller, also randomly chosen second wave of letters was mailed five months later, in order to study whether the effectiveness of the letters decreased over time.

In order to increase compliance with treatment assignment in the study sample, we were able to undertake a special procedure with the Chilean Postal Service to exclude firms with invalid postal addresses from both the treatment and the control group of the Letter Message Experiment, leaving a sample of 445,734 firms. This allowed me to reduce the share of treatment firms that did not receive the letter from around $26 \%$ to $6 \%$, thus substantially increasing statistical power. Table 2 presents summary statistics for the treatment groups in the Letter Message Experiment, compared to the control group. None of the differences in average characteristics between the treatment groups and the control group are statistically significant at the 10\%-level.

[Table 2]

Firms in the Letter Message Experiment pay an average of 264,000 pesos (equivalent to about 500 USD) in monthly VAT, with a median of approximately 70,000 (equivalent to about 140 USD). The large difference between the mean and the median indicates a very 
large dispersion in the distribution of tax payments. As discussed below, this dispersion has implications for the empirical specification of the analysis.

Firms in Chile are categorized into five groups by size, based on their sales revenues during the preceding tax year: micro, small, medium, large-sized firms, and firms with no sales in the preceding tax year. ${ }^{19}$ Micro-sized firms are by far the largest group, comprising $74.5 \%$ of the firms. The second largest group are small firms (18.2\%), followed by medium (2.8\%), and firms with no sales in the preceding year (1.5\%). The remaining three percent are new firms that have not been yet classified. Firms are also balanced across the treatment groups with respect to their position in the production chain: $28.8 \%$ are retailers that sell only to final consumers and $38.2 \%$ are intermediary firms that sell only to other firms. Overall, the share of sales that go to final consumers is $45.6 \%$.

\section{Implementation and Summary Statistics: Spillover Experiment}

The letters containing the audit pre-announcement for the Spillover Experiment were also sent in early December 2008, affecting tax payments starting in November 2008. The sample selected for this analysis consists of mostly rural, micro size firms, with tax declarations that show patterns suggestive of evasion. These firms had submitted VAT declarations regularly each month and had not been found guilty of any infractions, but they continually reported sales smaller than their input costs, without going out of business. ${ }^{20}$ Since many of these small firms were located in remote areas, there was a substantial fraction with no valid postal address. In these cases, the tax authority agreed to deliver the audit pre-announcement in person to the firms' location. They were able to reach $96 \%$ of assigned firms, but there were several weeks of delay for part of them.

Table 3, Columns (1) and (2) present summary statistics for the 5,600 firms in the original sample of the Spillover Experiment. None of the differences between treatment and control group are statistically significant at the $10 \%$ level. Since this sample was selected for having suspiciously high input costs compared to their sales, it is not surprising that their reported sales/input-ratio is suspiciously low, averaging only 0.67, and their actual mean declared VAT is negative. The mean of $-18,452$ pesos indicates that on average, these firms declare about 37 US dollars more in tax deduction from input costs than liabilities from sales, and the median VAT declaration is zero. The sample consists of very small, rural firms, mostly in remote areas: all are micro size, and they are among the smallest even within that category,

\footnotetext{
${ }^{19}$ Micro size firms sell less than the equivalent of 100,000 USD per year, small firms have sales between 100,000 and 1.1 million USD, medium size firms between 1.1 and 4.2 million USD, and large firms over 4.2 million USD.

${ }^{20}$ Even though sales can temporarily be lower than input costs, for example when firms make large investments into costly inputs, over the long-run, this pattern raises suspicion.
} 
with an average of 2.3 on the official firm size sub-classification within micro size, which ranges from 2 to $4 .{ }^{21}$ Compared to other firms in the country, they also have a smaller share of final sales (16\%), and are more likely to be in the agricultural sector (54\%).

[Table 3]

The fact that information about the trading partners was obtained during the audits lead to substantial attrition in the final sample for the Spillover Experiment. Due to administrative delays in the delivery of the audit notices, followed by the consequences of a very large earthquake, only about $27 \%$ of the 5,600 firms were actually audited, and they provided information about 2,829 trading partners. One potential concern of this attrition rate is that it might introduce selection bias if it creates differences between the treatment and control group within the remaining sample. Since the attrition was mainly driven by the degree to which an area was affected by the earthquake, it is plausibly exogenous to the randomly assigned treatment. Columns (3) and (4) of Table 3 suggest that this is indeed the case. Treatment and control firms do not differ in their probability of being audited and there is no significant difference in the characteristics of treatment and control firms among the audited sample, apart from a somewhat higher proportion of firms in the agricultural sector.

A separate potential issue is that firms that received a pre-announcement might have selectively removed or changed the trading partners in their books compared to those that did not receive a pre-announcement. There are several reason why this does not seem to be a concern in practice. First, as shown in Columns (5) and (6), trading partners of treated firms do not differ from those of control firms, except for a slightly lower share of months in which they failed to submit a declaration. Second, due to the audit method of the Chilean Tax Authority, such differential manipulations between treated and control firms are not very likely, since all audited firms, including those in the control group, receive an audit notice in written form weeks before they come in to the tax office to get audited. Finally, even if firms would have selectively removed their most delinquent trading partners from their books, this would actually lead to a downward biased estimate of the spillover effects.

As the rest of the balance table shows, overall, the trading partners in the Spillover Experiment are substantially larger than the audited firms, both in terms of their VAT paid and their official size category. The have about the same average age and a slightly higher share of their sales going to final consumers, and are much less likely to be in the agricultural sector. Their sales/input-ratio is in a much less suspicious range, with an average of 1.6. About $57 \%$ of trading partners are suppliers of the audited firms, while the rest are clients.

\footnotetext{
${ }^{21}$ Given that the official size classification is based on declared sales, and that this sample is suspected of under-declaring their true sales, this is likely to be an underestimate of the true size of these firms' operations.
} 


\subsection{Empirical Strategy}

The main outcome variable used is declared VAT, i.e. $19 \%$ of declared sales minus declared input costs. ${ }^{22}$ As discussed above, the dispersion of monthly declared VAT is very large. It ranges from -800 billion pesos (equivalent to -1.7 billion USD) to 16 billion pesos (33 million USD). For illustration, Figure A5 in the Appendix shows this very large dispersion, even excluding the top and bottom $5 \%$ of values. At the same time, there is a large density at zero. Such a large variance and the fat tails of the distribution imply that analyzing the impact of the intervention on the mean of declared VAT does not lead to any significant results, because the resulting variance is extremely large. I therefore use quantile regressions as well as linear probability models for the likelihood that declared VAT is larger than three key thresholds: (1) zero for the extensive margin, (2) VAT declared in the same month of the previous year, and (3) the predicted value based on the control group.

The latter two specifications have the advantage of not being sensitive to scale. This is important, given that much of the analysis does not focus on the overall impact of the treatment, but rather on the comparison of the response for different types of transactions or firms. Since the amount in pesos will mechanically be larger in larger types of transactions or firms, and the probability of declaring zero VAT will be smaller, both the quantile regressions and the extensive margin are not appropriate to analyze differential responses. For such comparisons, measures that captured relative changes are indicated.

Quantile regressions provide an indication of the magnitude of the impact, while being much less sensitive to extreme values than the mean. The specification used throughout is a difference-in-difference approach, comparing treated firms to control firms and pre-treatment to post-treatment period. The specification for the quantile regressions is therefore

$$
Q_{\tau}\left(V A T_{i t} \mid Z_{i}, t\right)=\alpha_{\tau}+\beta_{\tau}\left(Z_{i} \cdot p o s t\right)+\gamma_{\tau} Z_{i}+\partial_{t},
$$

where $Z_{i}$ is the treatment assignment dummy indicating that a firm is in the treatment group, $\partial_{t}$ stands for month fixed effects and $Z_{i} \cdot$ post indicates treatment, i.e. a firm in the treatment group in the post-treatment period.

The linear probability models are analyzed using the following specifications:

$$
T_{i t}=\alpha+\beta\left(Z_{i} \cdot \text { post }\right)+\gamma Z_{i}+\partial_{t}+e_{i t},
$$

\footnotetext{
${ }^{22}$ This value can be negative, as input costs can exceed sales in a given month. In this case the firm can carry the negative amount over to the next month as a tax credit. All measures used in this paper exclude the carry-over from the previous month, so that the analysis focuses on the new transactions in the current month.
} 
where $T_{i t}$ is the binary tax outcome for individual $i$ in month $t$. The probability of de-

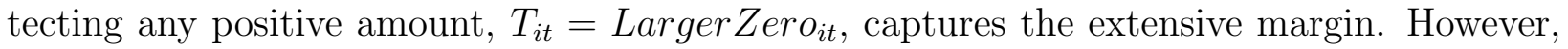
similar to the quantile regression, this measure will vary with the size of transactions or firms. For analysis of differential responses, a measure capturing relative change is required. One specification that satisfies this concern is the linear probability model with the outcome dummy indicating whether declared VAT is higher in the current month compared to the

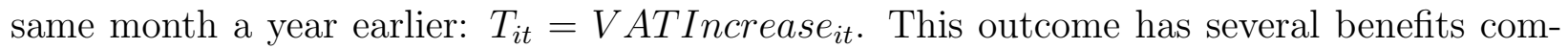
pared to alternative measures. First, as opposed to log specifications or count data models, it is applicable to variables that include zero or negative values, such as is the case for declared VAT. In addition, it provides a relative measure indicating a change in tax declarations compared to the firm's own history, it is robust against outliers, and at the same time takes into account firms in all parts of the VAT distribution. ${ }^{23}$

One possible remaining confounding factor could be differential time trends between different types of transactions, which could lead to differences in the probability of an increase compared to the previous year. As a robustness check, I therefore also run a specification with an outcome dummy that indicates whether declared VAT is higher than the predicted value for that firm in that month: $T_{i t}=$ LargerPredicted $_{i t}$. The prediction is based on median regressions among the firms in the control group and uses as predictors the firms' pre-treatment VAT payments, as well as those characteristics, for which differential treatment effects are evaluated in this paper, such as size and the share of sales to final consumers. ${ }^{24}$

When comparing the impact of the letter messages for different line-items, I use an additional within-firm estimation to hold any differential firm characteristics constant. For example, when comparing sales to input costs, there are two observations for each firm and month: one for its sales and one for its input costs. An interaction term between the type of transaction and treatment captures the differential impact on different line-items. Including the necessary controls, this gives the following regression:

$$
\text { LineItemIncrease }_{i t l}=\alpha+\beta\left(c_{i} \cdot \text { post }\right)+c_{i}+\partial_{t}+\phi\left(Z_{i} \cdot \text { post } \cdot l\right)+\eta(\text { post } \cdot l)+\iota_{l}+e_{i t l},
$$

where $l$ indicates the line-item, $c_{i}$ captures the firm fixed effects controlling for any between-

\footnotetext{
${ }^{23}$ One of the alternative specifications is quantile regressions using a normalized version of monthly tax payments in the form of monthly VAT/(pre-treatment average VAT). However, this specification is very sensitive to firms with very small pre-treatment averages, which end up with very high values when dividing by their pre-treatment value. Also, since the median of some line-items is zero, median regressions for these line-items are not informative, and the choice of alternative quantiles becomes to a certain extent arbitrary.

${ }^{24}$ Predicted medians are used instead of means, since due to the high variance, the predicted mean is again not very informative, and few firms end up close to their predicted mean. The predicting regression is therefore: $Q_{\tau}\left(V A T_{i} \mid\right.$ preV $\left.A T_{i}, X_{i}\right)=\alpha_{\tau}+\beta_{\tau}$ preV $A T_{i}+X_{i}^{\prime} \gamma_{\tau}$, where pre $V A T$ is the firm's average monthly VAT prior to November 2008.
} 
firm variation, and $c_{i} \cdot$ post captures firm fixed-effects times treatment period, to control for any differential trends within the firms. $\phi$ therefore represents the coefficient of interest: the differential response of line item $l$ for the treatment group in the treatment period.

All regression analysis of the Letter Message Experiment includes both waves of mailing. To this effect, treatment firms are included until four months after treatment (the time during which the overall effect of the deterrence letter is the strongest), which is until February 2009 for the first wave and June 2009 for the second, and control firms are included until June 2009. ${ }^{25}$ Since in the implementation of the Spillover Experiments some pre-announcement letters were delivered with delays, a six months post-treatment window is used in the Spillover Experiment. This corresponds to an average of four months after delivering of the letter, to be equivalent to the post-treatment window of the Letter Message Experiment. ${ }^{26}$

Given that the random variation affects only the firms' perceived audit probabilities, holding everything else constant, following Engel et al. (2001), I interpret changes in declared income in response to the randomized interventions as changes in tax evasion. There may, however, also be a response of real economic activity. The increased tax payments following the increased perceived audit risk reduce business profitability and may lead to increased prices, which, in turn, may decrease demand. All this may lead firms to reduce production. The observed increase in declared VAT may therefore be an underestimate of the reduction in evasion resulting from the treatment, since a reduction in production would lead to a decrease in declared VAT.

\section{Results}

\subsection{Letter Message Experiment}

The Letter Message Experiment examines how the VAT-generated paper trail interacts with tax enforcement for representative firms across Chile, by testing whether the increase in the expected audit probability induced by the deterrence letter has a lower effect on reporting of transactions that are subject to the VAT paper trail - i.e. transactions between two firms - compared to transactions that are not - i.e. sales to the final consumer. The following section first establishes the overall effectiveness of the deterrence message. It then shows

\footnotetext{
${ }^{25}$ Due to the random assignment, dropping one treatment group at an earlier date does not effect the validity of the results. All specifications include month fixed effects. Robustness checks using six posttreatment months, available upon request, show similar results.

${ }^{26}$ Results from a time-varying instrumental variables approach, aimed at calculating the corresponding Treatment-on-the-Treated effect (available upon request), find similar if slightly larger effects than the Intentto-Treat results reported in the paper. Robustness checks using four post-treatment months of the Intentto-Treat specification are similar, if somewhat less statistically significant.
} 
that this increase in the perceived audit probability indeed has a smaller impact where the VAT paper trail is present, even when looking at differential effects within firms, holding all firm characteristics constant.

\section{Overall Effectiveness of Deterrence}

Panel A in Figure 1 shows the impact of the deterrence letter on declared VAT of recipient firms, compared to the control group, which received no letter. The x-axis indicates time, with monthly observations. The vertical line represents the month when the letters were mailed. The graph shows the percent difference between medians of the treated and control firms in each month. We see a marked jump in tax payments after receipt of the deterrence letter. The median VAT income declared increases by about 12 percent and then slowly decreases again to reach the same levels as the control group after about 18 months. ${ }^{27}$ This large response speaks to the credibility of the Chilean Tax Authority in shifting firms' perceived monitoring risk and also indicates that firms do have scope to increase their tax declarations in the face of heightened deterrence.

[Figure 1]

Table A1 in the Appendix confirms the dynamics of the effect of the deterrence letter in regression form. The horizontal line marks the time of the mailing, with $t 1$ indicating the first month affected by the letter, and the rows below showing monthly effects through one year after mailing. Using the binary variables discussed above, it confirms the same pattern shown for the median in the graphical results above: a marked increase immediately after the mailing of the letter, and a steady decline thereafter. ${ }^{28}$ Given the large size of the treated group, it is of course plausible that there were spillover effects on the control group. This would bias the estimated effect of the treatment downwards since the spillover effects would reduce evasion in the control group as well.

In order to establish whether it is really deterrence that drives the effect, I compare the impact of the deterrence letter to that of the tax morale and placebo letters. Panels $\mathrm{B}$ and $\mathrm{C}$ of Figure 1 show their impact. In contrast to the deterrence letter, no marked increase is visible at the time of the mailing. The apparent first increase in Panel B happens before

\footnotetext{
${ }^{27}$ Figure A6 shows a similar pattern for the second wave of mailing. It indicates that even five months after the first wave, the deterrence message is perceived as credible. If anything, the treatment effect is stronger, increasing the median by up to $18 \%$. A possible reason is that tax evasion is suspected to have increased in this period due to a downturn in the economy. All regression analysis include both waves of mailing.

${ }^{28}$ Since the first four months have the strongest overall effect, all subsequent analysis for the Letter Message Experiment is conducted using four post-treatment months. Robustness checks using six post-treatment months, available upon request, show similar effects.
} 
mailing of the letter, and the second increase that occurs almost a year later is very unlikely to be due to the morale letter. The variance is larger due to the smaller sample size. This comparison shows that it is the content of the deterrence letter that drives the response, not simply the fact of receiving mail from the tax authority.

Table 4 shows the same result in regressions for the mean and the four outcome variables discussed above: median VAT, probability of declaring more than in the same month of the previous year, probability of declaring more than predicted, and probability of declaring any positive amount. All specifications confirm a highly significant impact of the deterrence message, except for the regression using mean VAT, which as expected does not provide statistically significant results. ${ }^{29}$

[Table 4]

\section{Interaction with the Paper Trail}

It is important to remember that evaluating the direct impact of the letters messages is not the focus of this paper. The goal is to use the randomly induced change in expected audit risk to back out information about the effectiveness of the VAT paper trail. Having established that the tax authority was able to credibly increase the expected audit probability, this section therefore turns to the analysis of the differential impact for transactions covered by the VAT paper trail. It first compares different types of transactions overall and then focuses on intra-firm analysis, in order to hold all firm-specific characteristics constant.

Table 5 displays the treatment effect of the deterrence message for the different types of transactions. The first two columns show the two components of the VAT: sales and input costs. By definition, input costs are based on transactions between firms and are therefore subject to a paper trail. If the paper trail has a preventive deterrence effect, one would therefore expect less of a response to the additional deterrence message for input costs than for sales. In line with the self-enforcement hypothesis, Columns (1) and (2) indeed show a significant response in sales, but not in input costs. The probability of increasing declared sales compared to the previous year increases highly significantly by $1.17 \%$, while there is an insignificant coefficient of $0.16 \%$ for input costs. ${ }^{30}$

\footnotetext{
${ }^{29}$ The tax morale letter only has a significant effect on the margin of declaring a positive amount. In line with this, quantile results not shown here find no significant effects overall, except for an increase by those with very low or negative declared VAT. For these firms, receiving a letter about high compliance by others may have a deterrence effect, as it may raise speculation that the tax authority suspects them of evasion.

${ }^{30}$ This of course does not mean that only $1.13 \%$ of the firms responded to treatment, as firms may for many other reasons be already above that threshold without the treatment, or far below it. The interpretation of these coefficients is the percent of firms that were pushed over the threshold of last year's payment due to the increase from treatment. These coefficients unfortunately do not have a very intuitive interpretation, but they are well equipped to show relative responses between different types of firms or transactions.
} 


\section{[Table 5]}

The Chilean tax forms allow me to further disentangle the effect by distinguishing two types of sales: intermediary sales to other firms and final sales to consumers, where the former are covered by the VAT paper trail and the latter are not. Columns (3) and (4) show that the effect is again concentrated on the type of transaction not covered by the paper trail, the sales to the final consumer. The probability of increasing final sales compared to the previous year goes up by $1.33 \%$ and is highly significant, while there is only a statistically insignificant effect of $0.12 \%$ for intermediate sales.

The above analysis excludes retail firms that sell only to final consumers, and upstream firms that sell only to other firms. This limits the degree to which the differential response is driven by cross-firm variation. Since by definition pure retailers cannot respond on intermediate sales or upstream firms on final sales. When including the entire universe of firms in the analysis (see Appendix Table A2), results are still consistent with the self-enforcing hypothesis. We see a much stronger response on sales than on inputs, and on final sales than on intermediate sales. In this sample, there is some response on inter-firm sales. However, this specification of course has to be interpreted with much caution, since many other characteristics that can affect the response to a deterrence message, such as firm size, tax morale, risk aversion, etc. could potentially be correlated with being a retailer or an upstream firm.

Even though Table 5 only compare transactions among firms that have both types of sales, we can go one step further in ruling out spurious effects stemming from variation between firms, by confirming these findings in a within-firm estimation in Table 6. The regressions in Table 6 follow the specification of Equation (3) in Section 3.4. This specification uses a data set that contains an observation for each line item for each firm in a given month. Including firm fixed effects and firm fixed effects times post-treatment period allows comparing the response to the deterrence message between different line items within a firm. Any observable or unobservable firm characteristics, both overall and for the treatment period, are thus held constant. ${ }^{31}$ Column (1) compares the effect between sales and input costs, and confirms that the response is clearly concentrated on sales, even when comparing transactions within the firm. Column (2) compares the impact between final and intermediary sales, and again finds that the response is much stronger in final than in intermediary sales.

[Table 6]

These results confirm that the finding of a lower response on transactions already covered by a paper trail is not driven by heterogeneity between firms. As discussed in Section 2.2

\footnotetext{
${ }^{31}$ To address the large computational demands of two sets of high-dimensional fixed effects, Stata routine reg2hdfe was used (Guimaraes and Portugal, 2010). Including fixed effects $X$ post did not change the results.
} 
above, considering that at a given level of evasion, an audit can be expected to be more effective where a paper trail is present, the fact that the response is lower on these transactions suggests that the paper trail had a preventive deterrence effect, leading to ex ante lower levels of evasion on transactions covered by the paper trail prior to the intervention. Through the indirect experimental approach (Khwaja and Mian, 2011) of injecting deterrence into the system and observing the differential response, we can back out an indication of lower evasion on transactions covered by a VAT paper trail.

While we can hold constant any heterogeneity between firms, such as firm owners' risk aversion and tax morale, firm size, industry, etc. the necessary assumption for this inference is that the lower response to the deterrence message is not driven by a difference within firms between their final sales and their other transactions. There are of course differences between final and intermediate transactions within a firm, since it is not randomly assigned whether the client is a consumer or another firm. We can also not test directly whether firms interpret the letter to target final sales in particular, though this did not seem to be the case based on the qualitative interviews I conducted when pre-testing the letters. The Spillover Experiment in Section 4.2 will therefore complement the findings of the Letter Message Experiment by showing the underlying mechanism in action.

\section{Interaction with Firm Size}

As discussed in Section 3.1, another dimension along which the information flows about tax liabilities are thought to vary is firm size. Differently to the VAT paper trail, where we can analyze types of transactions within a given firm, the analysis by firm size necessarily implies comparison across firms. Nevertheless, we can still see some interesting correlations. The following section shows how the treatment effect varies with firm size, and how this relates to the degree with which firms' sales are subject to the VAT paper trail.

Table 7 analyses how the treatment effect varies with both firm size and the share of sales going to final consumers. Column(1) shows that, consistent with the findings in the previous section, firms with a larger share of final sales respond more strongly to the deterrence letter. Columns (2) and (3) of Table 7 look at two different measures of firm size: the official twodigit Chilean size classification, based on firms' revenues in the preceding year, and the log of the number of employees in the pre-treatment year. For both measures, the treatment effect decreases with size. Figure A7 in the appendix also displays the impact based on three median regressions, one for each of the official Chilean size categories: micro, small and medium. This is consistent with the idea of Kleven et al. (2009) that larger firms evade fewer taxes since collusion is harder with a large number of employees. There may, of course, 
be many other reasons for this differential response by size. ${ }^{32}$ With respect to the VAT, the question arises whether the fact that small firms have a higher proportion of retail sales may be driving the differential response by firm size to some extent.

[Table 7]

Columns (4) and (5) include interactions of treatment with both the share of final sales and a size measure. As a result, the coefficients on the size measures are reduced significantly. In Panel A, looking at the probability of declaring more than in the previous year, the size coefficients are reduced by about 40 percent, but stay significant, while in Panel B, looking at the probability of declaring more than predicted, they are reduced by about two thirds, and are no longer statistically significant. The coefficient on the share of final sales stays highly significant in all specifications.

Since the specification in Panel B controls for differential trends for these different groups of firms over time, it provides the more reliable estimate. This would suggest that almost two thirds of the larger response in smaller firms can be explained by the larger degree to which their sales go to final consumers, and are therefore not covered by the VAT paper trail. However, this type of specific magnitude resulting from a horse-race regression between two correlated variables of course needs to be interpreted with much caution. ${ }^{33}$ Nevertheless, the results suggest that a significant part of the higher evasion in smaller firms may be driven by a weaker VAT paper trail.

\subsection{Spillover Experiment}

The Letter Message Experiment showed in the previous section that in Chile overall, in general equilibrium across the whole country, an increase in deterrence generates less of a response on transactions already covered by a VAT paper trail, suggesting that the paper trail has a preventive deterrence effect. The Spillover Experiment compliments these findings and is designed to find direct evidence for the underlying self-enforcing mechanism. As discussed in Section 3.2 above, the experiment injects deterrence into the system in this low compliance environment, to test for spillovers along the production chain. I measure

\footnotetext{
${ }^{32}$ Firms of different sizes may for example vary in their priors about the underlying audit probability, risk aversion, use of other sources of paper trails such as electronic billing, etc. An additional reason for lower evasion may be that in small firms, for example in a mom and pop store, the person making the evasion decision (e.g. whether or not to give a receipt) is also the residual claimant of the tax money saved, while in large firms, such as for example chain stores, this decision is usually made by an employee who does not benefit directly from evading the tax.

${ }^{33}$ If one of the variables is measured with more measurement error than the other, attenuation bias will lead it to look relatively less important.
} 
such spillovers by comparing VAT declarations for trading partners of the treated firms to trading partners of the control firms before and after the audit pre-announcement.

\section{[Table 8]}

Table 8 shows the impact of the audit pre-announcement on VAT payments of all trading partners. There is a significant increase in the declared VAT of related firms in the months following the audit pre-announcements, showing that the pre-announcement had compliance effects beyond the treated firm, promulgating through the network of their trading partners.

These results represent the first documentation of tax enforcement on one firm generating spillovers to other firms. Given these strong spillover effects, it might be in the interest of tax authorities to take these indirect effects into account, when designing an audit strategy. However, the overall spillover effects cannot by themselves establish that the channel is the VAT chain. Such spillovers could also simply result from a perception of a general increase in the audit risk by firms that are in communication with the treated firms.

Columns (3) and(4) of Table 8 therefore importantly test for the asymmetry in the prediction of the VAT self-enforcement hypothesis as detailed in Section 2.2 and displayed in Table 1. The spillover effects are shown separately for client and supplier firms. ${ }^{34}$ In line with the predictions, there are strong increases in declared VAT for suppliers, and no significant effects for client firms. This establishes the directionality of the spillover effects up the VAT chain. We can now rule out that the spillovers are simply the results of general conversations about the audit pre-announcement with trading partners, leading to an overall perception of increased audit risk in the area.

One remaining concern is that this differential effect might be driven by the fact that client and supplier firms are clearly different from each other. I therefore test for robustness of this result by including a series of control variables and their interaction with treatment, treatment period, etc. in Columns (5) and (6) of Table 8. The included control variables are firm size, the sales' input ratio (a proxy that the Chilean Tax Authority uses to assess suspicion of evasion), share of sales to the final customers (a measure of the degree to which the firm is an intermediate firm vs. a retailer), and finally a categorization of whether the firm's industry is classified by the tax authority as "hard-to-monitor." The findings remain robust even after inclusion of the control variables, indicating that it is not the different nature of supplier and client firms, but rather their position in the VAT chain that seems to be driving the result.

\footnotetext{
${ }^{34}$ The very small number of trading partners that show up both as a client and as a supplier of some of the audited firms are recorded both as a client and as a provider. All results are clustered at the level of the audited firm. Any spillovers between the treatment and control group can be expected to lead to a downward bias of the estimated spillover effects.
} 
The findings of the Spillover Experiment provide several insights. First, as predicted by the self-enforcement hypothesis, the built-in paper trail of the VAT leads to spillovers of enforcement along the production chain. Monitoring a firm increases tax payments by its upstream trading partners. Second, this indicates that when taking the whole network of firms into account, the paper trail globally acts as a complement to the audit probability: it augments the effectiveness of an increase in the audit probability for one firm, by increasing VAT payments by other firms.

Third, the mere existence of information through the paper trail - not surprisingly - is not in itself self-enforcing in an environment where the risk of cross-checks is low. Prior to the audit announcement introduced through this study, self-enforcement was incomplete at best among this sample of firms, even though a VAT system was in place. The small firms in this sample, mostly located in remote areas, were probably correctly anticipating that the risk of the tax authority double-checking their declarations was low. The additional deterrence effect resulting from the pre-announced audits was necessary to trigger the effectiveness of the VAT paper trail, indicating that it is only the interaction of information with deterrence that leads to effective tax enforcement.

\section{Conclusion}

This paper investigates the effectiveness of the Value Added Tax in facilitating tax enforcement and sheds light on the role of information and third-party paper trails for taxation. It provides the first micro-empirical evidence for the self-enforcing power of the paper trail in the VAT and for spillovers in tax enforcement through firms' trading networks more generally, and shows that in line with a growing recent literature, information reporting plays a crucial role for effective taxation.

Two randomized field experiments shed light on the role of the paper trail in the VAT. The Letter Message Experiment looks at the entire economy of Chile and investigates the deterrence effect of the VAT paper trail in general equilibrium in a well-functioning VAT system. It finds that holding firm characteristics constant, transactions that are already subject to the VAT paper trail respond much less to an increase in the perceived audit probability. Since for a given level of evasion, an audit can be expected to be more effective where a paper trail is present, the fact that the response is lower suggests that the paper trail had a preventive deterrence effect, leading to lower levels of evasion on transactions covered by the paper trail. In line with predictions of Kleven et al. (2009), the Letter Message Experiment also finds a stronger response for smaller firms. Controlling for the degree of 
retail sales reduces this differential response considerably, suggesting that a significant part of the higher evasion among smaller firms may be driven by a weaker paper trail.

The Spillover Experiment looks at the underlying dynamic that creates the preventive deterrence effect of the paper trail, and is designed to show the self-enforcing mechanism in action. It finds that as predicted by the self-enforcement hypothesis, increasing the audit probability of firms suspected of evasion generates spillovers up the VAT paper trail that lead to an increase of their suppliers' tax payments. These multiplier effects indicate that globally the VAT paper trail acts as a complement to the audit probability.

The combined findings of both experiments also show that while in Chile overall, the VAT paper trail seems to be highly effective, the mere existence of a VAT system, in the absence of credible deterrence, does not lead to "self-enforcement" - as exemplified by the low compliance among the sample of the Spillover Experiment prior to the intervention. It is the interaction of information with deterrence that leads to effective tax enforcement.

These results have a number of implications for public finance in developing countries and for tax policy in general. First, and most broadly, in line with findings from the literature on corruption and illegal capture of public funds, such as Reinikka and Svensson (2004), the conclusions confirm that verifiable paper trails on financial flows can provide a powerful tool, rendering misappropriation of funds more difficult.

Second, the results are informative for the choice of tax instruments. They suggest that forms of taxation such as the VAT, which leave a stronger paper trail and thereby generate more information for the tax authority, provide an advantage for tax collection over other forms of taxation, such as a retail sales tax. Other mechanisms that provide information to the government, such as online billing systems or electronic receipts, as recently introduced by Brazil and Kenya, may have high returns. Further research is required to investigate the effectiveness of such mechanisms, as well as the dimensions of generalizability of these findings. For example, the Chilean Tax Authority has a reputation of being highly effective and having low levels of corruption. So the question arises how this may affect the results. On one hand, the paper trail may be more important in high corruption environments, as it reduces the discretion of tax officials (e.g. Baurer, 2005). At the same time, the paper trail may be less effective where enforcement can be circumvented by paying off the tax auditor.

Third, the spillover effects are relevant for the design of optimal audit strategies. When choosing which firms to audit, a tax authority may not only want to consider the expected impact on the audited firm, but also the multiplier effect through a firm's trading network. In particular, the higher response in final sales and spillovers along the supply chain suggest that increasing the audit probability at the end of the production chain is beneficial both because it yields higher direct returns and because the spillovers will transmit the effect up 
the production chain. At the same time, enforcement at the final sales stage is also more costly, given the absence of a paper trail and the smaller average firm size. Further research is required to analyze how to optimally allocate audit probabilities to different nodes in the network.

Fourth, as Emran and Stiglitz (2005) point out, the VAT is only effective among firms in the formal sector, and a heavy reliance on the VAT can therefore increase the inter-sectorial distortions between formal and informal sectors. De Paula and Scheinkman (2010) find that where the VAT is present, formalized firms tend to trade with other formalized firms, since these can provide them with receipts that allow them to deduct the input costs from VAT payments, while informal firms tend to trade among themselves. Combined with the spillover findings, this suggests that enforcing formalization at the final stage of production might potentially contribute to formalizing entire production chains.

Fifth, the differential enforcement through the paper trail at different production stages leads to differences in effective tax rates and potential distortions in the market. If the evasion rate is higher for downstream firms, a flat VAT rate will result in upstream firms paying a higher effective tax rate. This difference in the tax rate may lead to incentives for increased vertical integration at the last production stage and can create distortions in production between intermediary goods and final goods. On the other hand, if small firms can evade more, this may lead firms to stay inefficiently small to reduce their effective tax burden. Further research is required to investigate whether such distortions will be economically significant and warrant a revision of the frequently postulated recommendation that, putting aside redistributive considerations, a flat nominal VAT rate is optimal (e.g. Ebrill, 2001).

Finally, the results suggest a possible explanation for the differences in tax evasion between developed and developing economies. In many developing countries, home production plays an important role, gains from trade and division of labor are relatively small, and production chains tend to be shorter. Moreover, if gains from trade are small, division of labor may not only be low, but also more elastic with respect to taxation. If the division of labor leads to transactions between agents, which - in contrast to home production - are traceable by the tax authority, small taxes may be enough to discourage such divisions and thereby erode the traceable tax base. All these factors may make it harder for developing countries to develop an effective tax system, since they reduce the number of transactions that can lead to verifiable paper trails - through the VAT or through other forms of third-party reporting. 


\section{References}

Adimark, "Imagen del Servicio de Impuestos Internos," Santiago de Chile 2006.

Agha, Ali and Jonathan Haughton, "Designing VAT Systems: Some Efficiency Considerations," The Review of Economics and Statistics, 1996, 78 (3), 303-308.

Allingham, Michael G. and Agnar Sandmo, "Income Tax Evasion: A Theoretical Analysis," Journal of Public Economics, 1972, 1 (3-4), 323-338.

Alm, James, John A. Deskins, and Michael McKee, "Do Individuals Comply on Income not Reported by Their Employer?," Research Paper Series 07-34, Andrew Young School of Policy Studies 2007.

Andreoni, James, Brian Erard, and Jonathan Feinstein, "Tax Compliance," Journal of Economic Literature, 1998, 36 (2), 818-860.

Baurer, Lewis I., "Tax Administrations and Small and Medium Enterprises (SMEs) in Developing Countries," The World Bank 2005.

Besley, Tim and Torsten Persson, "Public Finance and Development," in A. J. Auberach and M. S. Feldstein, eds., Draft Chapter for the Handbook of Public Economics, 2012.

Bird, Richard and Pierre-Pascal Gendron, The VAT in Developing and Transitional Countries, Cambridge University Press, 2007.

Burgess, Robin and Nicholas Stern, "Taxation and Development," Journal of Economic Literature, 1993, 31 (2), 762-830.

Carrillo, Paul, M Shahe Emran, and Anita Rivadeneira, "Do Cheaters Bunch Together? Profit Taxes, Withholding Rates and Tax Evasion," Working Paper, George Washington University 2012 .

Dal Bó, Ernesto and Petro Dal Bó, "Do the Right Thing: The Effects of Moral Suasion on Cooperation," NBER Working Papers 15559, National Bureau of Economic Research 2009.

Das-Gupta, Arindam and Ira N. Gang, "Value Added Tax Evasion, Auditing and Transactions Matching," in J. McLaren, ed., Institutional Elements of Tax Design and Reform, Washington, D.C.: The World Bank Technical Paper No. 539, 2003.

De Paula, Aureo and Jose A. Scheinkman, "Value-Added Taxes, Chain Effects, and Informality," American Economic Journal: Macroeconomics, 2010, 2 (4).

Ebrill, Liam, The Modern VAT, International Monetary Fund, 2001.

Emran, Shahe and Joseph Stiglitz, "On Selective Indirect Tax Reform in Developing Countries," Journal of Public Economics, 2005, 89 (4), 599-623.

Engel, Eduardo, Alexander Galetovic, and Claudio E. Raddatz, "Estimacion de la Evasion del IVA Mediante el Metodo de Punto Fijo," Estudios Tributarios. Internal Revenue Service, Santiago, Chile, 1998.

_ , _ , and _ , "A Note on Enforcement Spending and VAT Revenues," Review of Economics and Statistics, 2001, 83 (2), 384-387.

Engstrom, Per and Patrik Hesselius, "The Information Theory: Theory and Application," Working Paper 17, Institute for Labour Market Policy Evaluation 2007. 
Feld, Lars and Bruno S. Frey, "Trust Breeds Trust: How Taxpayers are Treated," Economics of Governance, 2002, 3 (2), 87-99.

Fellner, Gerlinde, Rupert Sausgruber, and Christian Traxler, "Testing Enforcement Strategies in the Field: Legal Threat, Moral Appeal and Social Information," Journal of the European Economic Association, Forthcoming.

Fisman, Raymond and Shang-Jin Wei, "Tax Rates and Tax Evasion: Evidence from Missing Imports in China," Journal of Political Economy, 2004, 112, 471-500.

Gordon, Roger H. and Wei Li, "Tax Structures in Developing Countries: Many Puzzles and a Possible Explanation," Journal of Public Economics, 2009, 93 (7-8), 855-866.

Grinberg, Itai, "Where Credit is Due: Advantages of the Credit-Invoice Method for Partial Replacement VAT," Tax Law Review, 2010, 63 (2).

Guimaraes, Paulo and Pedro Portugal, "A Simple Feasible Alternative Procedure to Estimate Models with High-Dimensional Fixed Effects," Stata Journal, 2010, 10 (4), 628-649.

Hemming, Richard and John Kay, "The United Kingdom, In The Value Added Tax: Lessons from Europe," in H.J. Aaron, ed., H.J. Aaron, ed., Chicago: Washington: Brookings Institution, 1981.

Internal Revenue Service, "Federal Tax Compliance Research: Individual Income Tax Gap Estimates for 1985, 1988, and 1992," IRS Publication - Washington, D.C 1415 (Rev. 4-96) 1996.

_, "Updated Estimates of the Tax Year 2001 Individual Income Tax Underreporting Gap," Overview - Washington, D.C. 2006.

_ , "Congressional Justification," Washington, D.C. 2008.

Keen, Michael and Ben Lockwood, "The Value Added Tax: its Causes and Consequences," Journal of Development Economics, 2010, 92 (2), 138-151.

- and Stephen Smith, "VAT Fraud and Evasion: What Do We know and What Can Be Done?," National Tax Journal, 2006, LIX(4), 861-887.

Khwaja, Asim Ijaz and Atif R. Mian, "Rent Seeking and Corruption in Financial Markets," Annual Review of Economics, 2011, 3, 579-600.

Kleven, Henrik J. and Mazhar Waseem, "Behavioral Responses to Notches: Evidence from Pakistani Tax Records," Working Paper Series, London School of Economics 2012.

_, Claus T. Kreiner, and Emmanuel Saez, "Why can Modern Governments Tax so Much? An Agency Model of Firms as Fiscal Intermediaries," NBER Working Papers 15218, National Bureau of Economic Research 2009.

_, Martin Knudsen, Claus T. Kreiner, Soren L. Pedersen, and Emmanuel Saez, "Unwilling or Unable to Cheat? Evidence from a Tax Audit Experiment in Denmark," Econometrica, 2011, 79 (3), 651-692.

Kopczuk, Wojciech and Joel Slemrod, "Putting Firms into Optimal Tax Theory," The American Economic Review: Papers and Proceedings, 2006, 96 (2), 130-134.

Kumler, Todd J., Eric A. Verhoogen, and Judith Frias, "Enlisting Workers in Monitoring Firms: Payroll Tax Compliance in Mexico," Columbia University Department of Economics Discussion Papers, 2012, 96. 
Ludwig, Jens, Jeffrey R. Kling, and Sendhil Mullainathan, "Mechanism Experiments and Policy Evaluations," NBER Working Papers 17062, National Bureau of Economic Research 2011.

Marshall, Cristobal and Dina Pomeranz, "Improving Tax Audit Strategies through Randomized Enforcement Messages: Methodology and Application in Chile," Working Paper, 2011.

Mideplan, "Resultados CASEN 2009: Nuevas Cifras de Distribucion del Ingreso," Ministerio de Planificación - Gobierno de Chile 2010.

Nellor, David, "The Effect of the Value-Added Tax on the Tax Ratio," IMF Working Papers 87/47, International Monetary Fund 1987.

Olken, Benjamin A. and Monica Singhal, "Informal Taxation," American Economic Journal: Applied Economics, 2011, 3 (4).

Reinikka, Ritva and Jakob Svensson, "The Power of Information: Evidence from a Newspaper Campaign to Reduce Capture," World Bank Policy Research Working Paper 3239, The World Bank 2004.

Rincke, Johannes and Christian Traxler, "Enforcement Spillovers," The Review of Economics and Statistics, 2011, 93 (4), 1224-34.

Schneider, Friedrich, Andreas Buehn, and Claudio E. Montenegro, "Shadow Economies All Over the World: New Estimates for 162 Countries from 1999 to 2007," World Bank Discussion Papers, The World Bank 2010.

Servicio de Impuestos Internos, "Ingresos Tributarios Anuales 1993 a 2009," Santiago de Chile 2010 .

_, "Tasa de Evasion IVA 1990-2008," Subdireccion de Estudios. Santiago de Chile 2010.

_, "Impuesto al Valor Agregado (IVA)," http://www.sii.cl/portales/inversionistas/imp_ chile/impuestos_iva_ing.htm, April 2011. Accessed: 19/11/2012.

Slemrod, Joel, "Does It Matter Who Writes the Check to the Government? The Economics of Tax Remittance," National Tax Journal, 2008, 61 (2), 251-75.

_ and Shlomo Yitzhaki, "Tax avoidance, evasion, and administration," in A. J. Auberach and M. S. Feldstein, eds., Handbook of Public Economics, 2002.

_ , Marsha Blumenthal, and Charles Christian, "Taxpayer Response to an Increased Probability of Audit: Evidence from a Controlled Experiment in Minnesota," Journal of Public Economics, 2001, 79 (3), 455-483.

Tait, Alan, Value Added Tax, London, New York: McGraw-Hill, 1972.

United States Office of Management and Budget, "Budget of the United States Government, Fiscal Year 2009," Washington, DC 2008. 


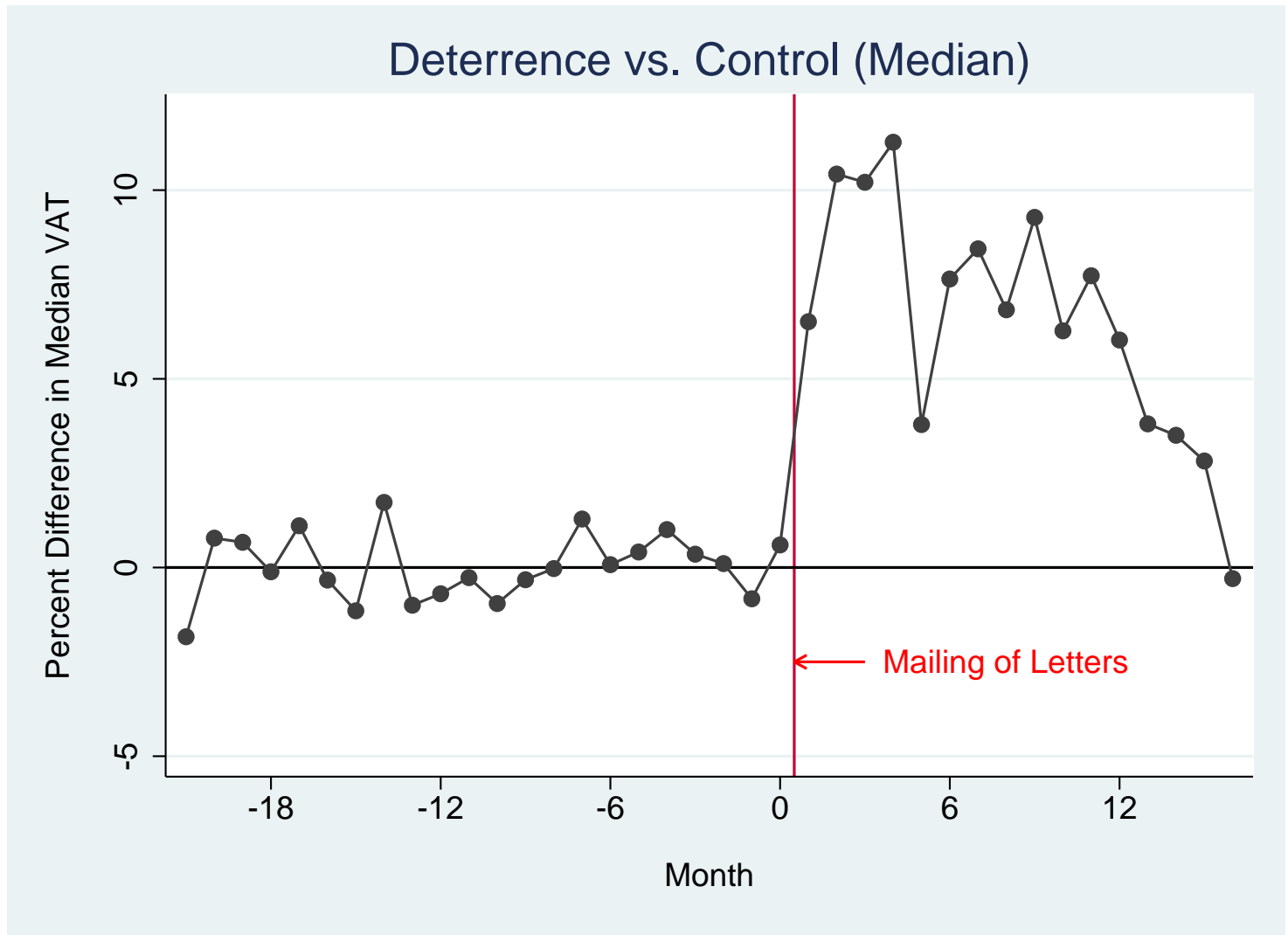

Panel A

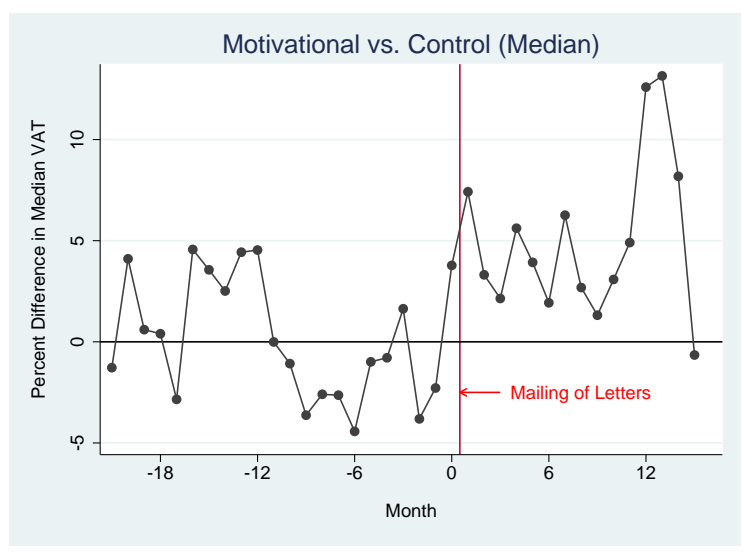

Panel B

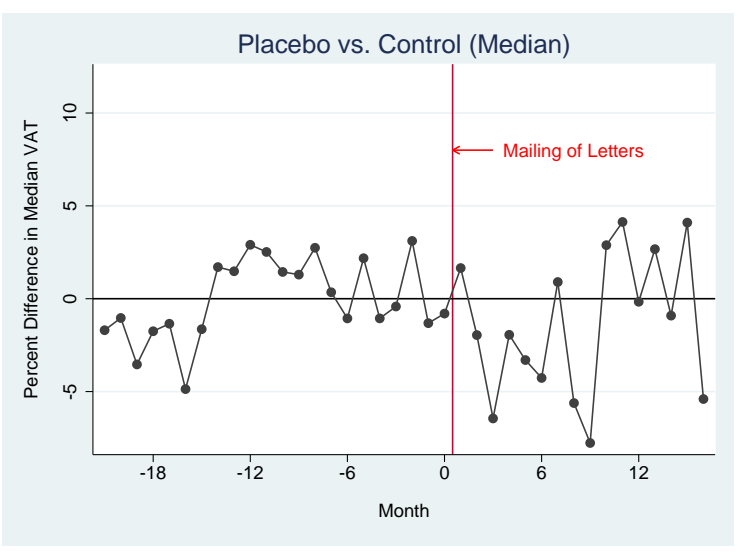

Panel C

Figure 1: Impact of the three types of letters

Notes: This figure plots the monthly percent difference between the medians of the treatment and the control group for each type of letter: (median VAT treatment group - median VAT control group) / (median VAT control group), normalizing pre-treatment percent difference to zero. The y-axis indicates time, with monthly observations, and zero indicates the last month before the mailing of the letters. The vertical line marks mailing of the letters. The figure shows the first wave of mailing. For the second (much smaller) wave of mailing, see Figure A6. 
Table 1: Two Forms of VAT Evasion on Inter-Firm Transactions

\begin{tabular}{lcccc}
\hline \hline Position in supply chain & \multicolumn{2}{c}{ Omission } & Discrepancies \\
\hline \hline Supplier & Sales $\uparrow$ & VAT $\uparrow$ & Sales $\uparrow$ & VAT $\uparrow$ \\
Treated firm & $\begin{array}{c}\text { Inputs } \uparrow \\
\text { Sales } \uparrow\end{array}$ & VAT ( $\uparrow)$ & $\begin{array}{c}\text { Inputs } \downarrow \\
\text { Sales } \uparrow\end{array}$ & VAT $\uparrow$ \\
\hline Client & Inputs $\uparrow$ & VAT $\downarrow$ & Inputs $\downarrow$ & VAT $\uparrow$ \\
\hline \hline
\end{tabular}

Notes: "Omission" stands for the type of evasion where a transaction is omitted from the books of both the seller and the buyer firm. "Discrepancies" stands for the type of evasion where the books of the seller and the buyer reveal discrepancies. Buyers, for whom inputs represent a tax deduction, will tend to overstate the value of the transaction, while sellers, for whom the transaction represents a tax liability, will tend to understate its value. The arrows indicate the expected direction of change for the line item in question resulting from an increased audit probability on the treated firm. 
Table 2: Letter Message Experiment: Baseline Summary Statistics and Balance of Randomization

\begin{tabular}{lcccc}
\hline \hline & $(1)$ & $(2)$ & $(3)$ & $(4)$ \\
& Control Group & $\begin{array}{c}\text { Difference } \\
\text { to Deterrence }\end{array}$ & $\begin{array}{c}\text { Difference } \\
\text { to Tax Morale }\end{array}$ & $\begin{array}{c}\text { Difference } \\
\text { to Placebo }\end{array}$ \\
\hline \hline Monthly VAT (mean) & 264,029 & 3,105 & 305 & $-10,565$ \\
Monthly VAT (median) & $(1,871)$ & $(3,744)$ & $(7,869)$ & $(7,472)$ \\
& 69,892 & -779 & $-1,841$ & 7 \\
Firm age in months & $(458)$ & $(920)$ & $(1,959)$ & $(1,836)$ \\
& 108 & -0.32 & -0.43 & -0.60 \\
\% Non-filed declarations & $(0.12)$ & $(0.25)$ & $(0.51)$ & $(0.51)$ \\
& 4.3 & -0.03 & -0.07 & -0.02 \\
\% No sales year prior & $(0.02)$ & $(0.05)$ & $(0.10)$ & $(0.10)$ \\
\% Micro size & 1.5 & -0.05 & 0.06 & -0.01 \\
\% Small size & $(0.02)$ & $(0.04)$ & $(0.09)$ & $(0.09)$ \\
\% Medium size & 74.5 & -0.04 & -0.28 & -0.6 \\
& $(0.08)$ & $(0.16)$ & $(0.33)$ & $(0.33)$ \\
\% Retail firms & 18.2 & 0.028 & 0.102 & -0.055 \\
\% Intermediary firms & $(0.07)$ & $(0.14)$ & $(0.29)$ & $(0.29)$ \\
& 2.8 & 0.01 & 0.02 & 0.07 \\
\% Final sales & $(0.03)$ & $(0.06)$ & $(0.12)$ & $(0.13)$ \\
& 28.7 & -0.06 & -0.28 & -0.13 \\
& $(0.08)$ & $(0.16)$ & $(0.34)$ & $(0.34)$ \\
Number of firms & 38.2 & 0.15 & 0.31 & -0.08 \\
\hline \hline & $(0.09)$ & $(0.18)$ & $(0.37)$ & $(0.37)$ \\
& 45.6 & -0.10 & -0.29 & -0.07 \\
& $(0.08)$ & $(0.17)$ & $(0.35)$ & $(0.35)$ \\
\hline
\end{tabular}

Notes: Each row shows a regression of the pre-treatment variable in question on treatment dummies and a constant term. The constant term captures the value for the control group. Monthly VAT winzorized at the top and bottom $0.1 \%$. Columns (2)-(4) show the difference of the treatment groups to the control group. None of the differences are statistically significant at the 10\%-level. Monetary amounts are in Chilean pesos, with 500 pesos approximately equivalent to 1 USD. Robust standard errors in parentheses, clustered at the firm level for all variables except for median tax paid, for which the table shows the result of a median regression for October 2008, the month before the tax payment. All other observations are monthly for ten months prior to treatment (from January 2008). 
Table 3: Spillover Experiment: Baseline Summary Statistics and Balance of Randomization

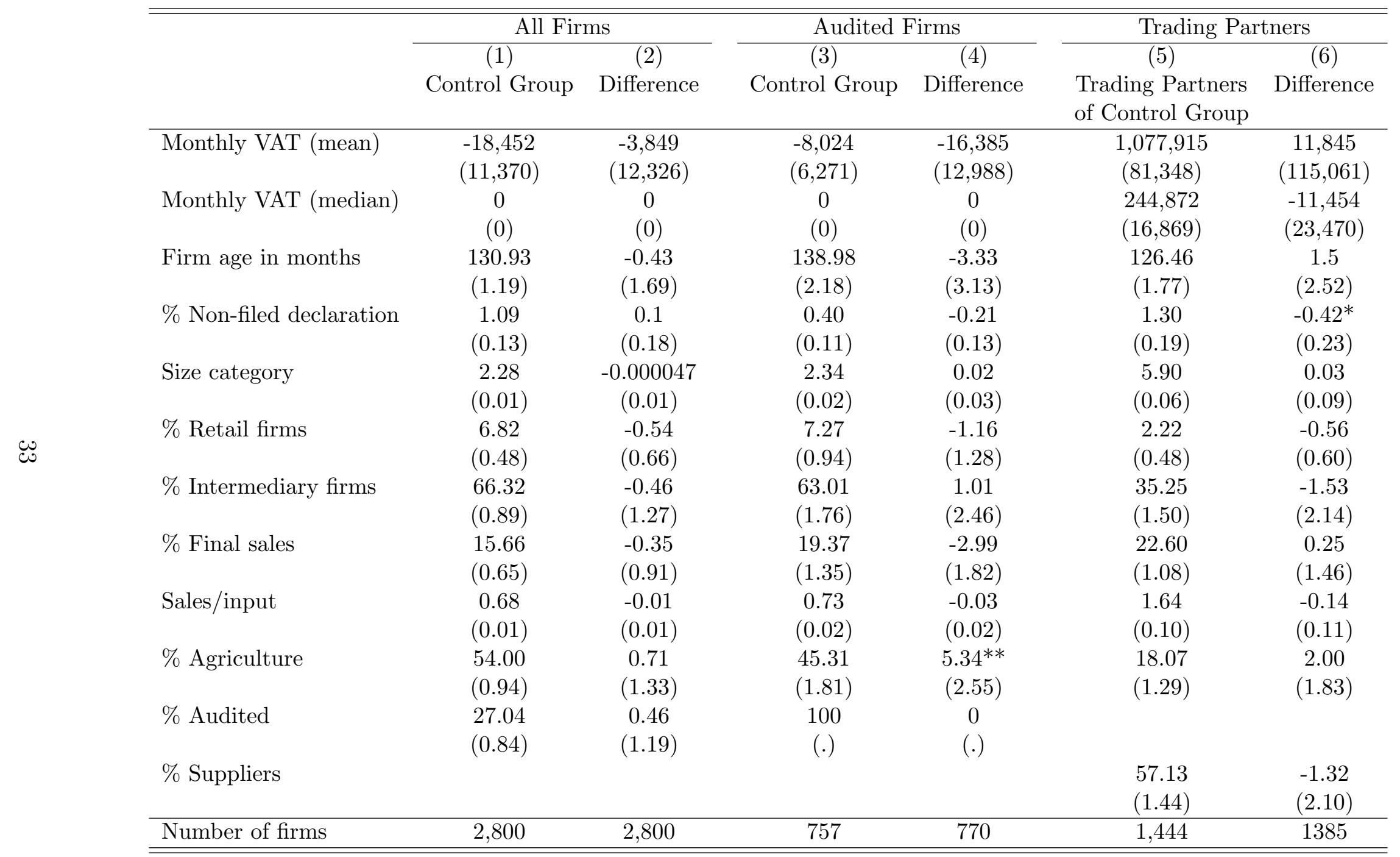

Notes: This table shows summary statistics for the pre-treatment period and balance of randomization for three groups: the 5,600 firms in the sample of the Spillover Experiment, the firms that were actually audited, and the trading partners of the audited firms. Each row shows three regressions of the pre-treatment variable in question on a dummy indicating treatment assignment and a constant term: Columns (1) and (2) for the firms in the full Spillover Experiment sample, Columns (3) and (4) for the audited firms, and Columns (5) and (6) for the trading partners. Observations are monthly for ten months prior to treatment, starting in January 2008. The constant terms shown in Columns (1), (3) and (5) capture the values for the control group. Columns (2), (4) and (6) show the difference of the treatment group to the control group. Monetary amounts are in Chilean pesos, with 500 Chilean pesos approximately equivalent to 1 USD. Robust standard errors in parentheses, clustered at the firm level for Columns (1) to (4) and at the audited firm's level for Columns (5) and (6). ${ }^{* * *}=\mathrm{p}<0.01,{ }^{* *}=\mathrm{p}<0.05,{ }^{*}=\mathrm{p}<0.1$ 
Table 4: Letter Message Experiment: Intent-to-Treat Effects on VAT Payments by Type of Letter

\begin{tabular}{|c|c|c|c|c|c|}
\hline & $\begin{array}{c}(1) \\
\text { Mean VAT }\end{array}$ & $\begin{array}{c}(2) \\
\text { Median } \\
\text { VAT }\end{array}$ & $\begin{array}{c}(3) \\
\text { Percent VAT > } \\
\text { Previous Year }\end{array}$ & $\begin{array}{c}(4) \\
\text { Percent VAT > } \\
\text { Predicted }\end{array}$ & $\begin{array}{c}(5) \\
\text { Percent VAT } \\
>\text { Zero }\end{array}$ \\
\hline Deterrence letter X post & $\begin{array}{l}-1144 \\
(2804)\end{array}$ & $\begin{array}{c}5,302^{* * *} \\
(1,214)\end{array}$ & $\begin{array}{c}1.40^{* * *} \\
(0.12)\end{array}$ & $\begin{array}{c}1.42^{* * *} \\
(0.10)\end{array}$ & $\begin{array}{c}0.53^{* * *} \\
(0.09)\end{array}$ \\
\hline Tax morale letter $\mathrm{X}$ post & $\begin{array}{l}-1840 \\
(6082)\end{array}$ & $\begin{array}{c}1,419 \\
(2,552)\end{array}$ & $\begin{array}{c}0.40 \\
(0.25)\end{array}$ & $\begin{array}{c}0.30 \\
(0.22)\end{array}$ & $\begin{array}{c}0.44^{* *} \\
(0.20)\end{array}$ \\
\hline Placebo letter X post & $\begin{array}{c}835 \\
(6243)\end{array}$ & $\begin{array}{c}1,430 \\
(2,598)\end{array}$ & $\begin{array}{c}-0.11 \\
(0.26)\end{array}$ & $\begin{array}{c}-0.19 \\
(0.23)\end{array}$ & $\begin{array}{c}-0.14 \\
(0.20)\end{array}$ \\
\hline Constant & $\begin{array}{c}268810^{* * *} \\
(1799)\end{array}$ & $\begin{array}{c}69,459^{* * *} \\
(432)\end{array}$ & $\begin{array}{c}47.50^{* * * *} \\
(0.07)\end{array}$ & $\begin{array}{c}48.27^{* * *} \\
(0.07)\end{array}$ & $\begin{array}{c}67.30^{* * *} \\
(0.06)\end{array}$ \\
\hline Month fixed effects & Yes & Yes & Yes & Yes & Yes \\
\hline Firm fixed effects & Yes & No & Yes & Yes & Yes \\
\hline Treatment Assignment & No & Yes & No & No & No \\
\hline Number of observations & $7,892,076$ & 445,734 & $7,892,076$ & $7,892,076$ & $7,892,076$ \\
\hline Number of firms & 445,734 & 445,734 & 445,734 & 445,734 & 445,734 \\
\hline Adjusted $R^{2}$ & 0.40 & & 0.14 & 0.28 & 0.47 \\
\hline
\end{tabular}

Notes: Column (1) shows a regression of the mean declared VAT on treatment dummies, winzorized at the top and bottom 0.1\%. Column (2) shows a median regression of the mean post-treatment VAT, and Columns (3)-(5) show linear probability regressions of the probability of an increase in declared VAT since the previous year, the probability of declaring more than predicted and the probability of declaring any positive amount. Coefficients and standard errors of the linear probability regressions are multiplied by 100 to express effects in percent. Monetary amounts are in Chilean pesos, with 500 Chilean pesos approximately equivalent to 1 USD. Standard errors in parentheses, robust and clustered at the firm level for Columns (1) and (3)-(5). ${ }^{* * *} \mathrm{p}<0.01,{ }^{* *} \mathrm{p}<0.05,{ }^{*} \mathrm{p}<0.1$. 
Table 5: Impact of Deterrence Letter on Different Types of Transactions

\begin{tabular}{lcccc}
\hline \hline & $(1)$ & $(2)$ & $(3)$ & $(4)$ \\
& Percent Sales & Percent Input Costs & Percent Intermediary & Percent Final Sales \\
& $>$ & $>$ & Sales $>$ & $>$ \\
& Previous Year & Previous Year & Previous Year & Previous Year \\
\hline Deterrence letter X post & $1.17^{* * *}$ & 0.16 & 0.12 & $1.33^{* * *}$ \\
& $(0.22)$ & $(0.21)$ & $(0.19)$ & $(0.21)$ \\
Constant & $55.39^{* * *}$ & $53.25^{* * *}$ & $38.37^{* * *}$ & $(0.12)$ \\
Month fixed effects & $(0.13)$ & $(0.13)$ & Yes & $(0.12)$ \\
Firm fixed effects & Yes & Yes & Yes & Yes \\
\hline Number of observations & Yes & Yes & $2,392,529$ & $2,392,529$ \\
Number of firms & $2,392,529$ & $2,392,529$ & 133,156 & 133,156 \\
Adjusted $R^{2}$ & 133,156 & 133,156 & 0.30 & 0.32 \\
\hline \hline
\end{tabular}

Notes: Regressions of the probability of the line item (total sales, total input costs, intermediary sales, and final sales) being higher than in the same month the previous year. Sample of firms that have both final and intermediary sales in the year prior to treatment. Coefficients and standard errors are multiplied by 100 to express effects in percent. Robust standard errors in parentheses, clustered at the firm level. ${ }^{* * *} \mathrm{p}<0.01$, ** $\mathrm{p}<0.05,{ }^{*} \mathrm{p}<0.1$. 
Table 6: Within-Firm Estimator of Differential Response by Type of Transaction

\begin{tabular}{lcc}
\hline \hline & $\begin{array}{c}\text { Percent Line-Item }> \\
\text { Previous Year }\end{array}$ & $\begin{array}{c}\text { Percent Line-Item }> \\
\text { Previous Year }\end{array}$ \\
\hline Deterrence letter X sales X post & $1.26^{* * *}$ & \\
Deterrence letter X final sales X post & $(0.17)$ & $1.23^{* * *}$ \\
Sales & & $(0.23)$ \\
& $1.98^{* * *}$ & \\
Final sales & $(0.51)$ & $5.64^{* * *}$ \\
& & $(0.12)$ \\
Sales X post & & Yes \\
Final Sales X post & & Yes \\
Firm fixed effects X post & Yes & Yes \\
Month fixed effects & Yes & Yes \\
Firm fixed effects & Yes & $4,785,058$ \\
Number of observations & $4,785,058$ & 133,156 \\
Number of firms & 133,156 & 0.24 \\
$R^{2}$ & 0.32 & \\
\hline \hline
\end{tabular}

Notes: Regression of the probability of the line item being higher than in the same month the previous year in a data set that contains multiple line items per firm and month. Column (1) compares increases in sales to increases in input costs within a given firm, Column (2) compares final sales to intermediate sales. The reg2hdfe routine (Guimaraes and Portugal, 2010), used to produce the large number two-level fixed effects (firm fixed effects and firm fixed effect X post), does not produce a constant term. Sample of firms that have both final and intermediary sales in the period prior to treatment. Coefficients and standard errors are multiplied by 100 to express effects in percent. Sample contains all firms that have both final and intermediary sales in the period prior to treatment. Robust standard errors in parentheses, clustered at the firm level. ${ }^{* * *} \mathrm{p}<0.01,{ }^{* *} \mathrm{p}<0.05,{ }^{*}$ $\mathrm{p}<0.1$. 
Table 7: Interaction of Firm Size and Share of Sales to Final Consumers

\begin{tabular}{|c|c|c|c|c|c|}
\hline \multirow[t]{2}{*}{ Panel A: } & \multicolumn{5}{|c|}{ Percent VAT $>$ Previous Year } \\
\hline & (1) & $(2)$ & (3) & (4) & (5) \\
\hline Deterrence letter X final sales share & $\begin{array}{c}1.61^{* * *} \\
(0.26)\end{array}$ & & & $\begin{array}{c}1.48^{* * *} \\
(0.27)\end{array}$ & $\begin{array}{c}1.43^{* * *} \\
(0.26)\end{array}$ \\
\hline Deterrence letter X size category & & $\begin{array}{c}-0.17^{* * *} \\
(0.04)\end{array}$ & & $\begin{array}{c}-0.10^{* * *} \\
(0.04)\end{array}$ & \\
\hline Deterrence letter X log employees & & & $\begin{array}{c}-0.45^{* * *} \\
(0.11)\end{array}$ & & $\begin{array}{c}-0.29^{* *} \\
(0.12)\end{array}$ \\
\hline Deterrence letter & $\begin{array}{c}0.68^{* * *} \\
(0.16)\end{array}$ & $\begin{array}{c}2.63^{* * *} \\
(0.29)\end{array}$ & $\begin{array}{c}1.66^{* * *} \\
(0.13)\end{array}$ & $\begin{array}{c}1.49 * * * \\
(0.35)\end{array}$ & $\begin{array}{c}0.92^{* * *} \\
(0.19)\end{array}$ \\
\hline Constant & $\begin{array}{c}47.53^{* * *} \\
(0.08)\end{array}$ & $\begin{array}{c}48.87^{* * * *} \\
(0.08)\end{array}$ & $\begin{array}{c}47.50^{* * *} \\
(0.08)\end{array}$ & $\begin{array}{c}48.89^{* * *} \\
(0.08)\end{array}$ & $\begin{array}{c}47.53^{* * *} \\
(0.08)\end{array}$ \\
\hline Final sales share $\mathrm{X}$ post & Yes & No & No & Yes & Yes \\
\hline Size measure $\mathrm{X}$ post & No & Yes & Yes & Yes & Yes \\
\hline Firm fixed effects & Yes & Yes & Yes & Yes & Yes \\
\hline Month dummies & Yes & Yes & Yes & Yes & Yes \\
\hline Observations & $7,308,631$ & $7,116,590$ & $7,340,994$ & $7,084,823$ & $7,308,631$ \\
\hline Number of Firms & 406,834 & 396,135 & 408,636 & 394,367 & 406,834 \\
\hline Adjusted $R^{2}$ & 0.14 & 0.14 & 0.14 & 0.14 & 0.14 \\
\hline \multirow[t]{2}{*}{ Panel B: } & \multicolumn{5}{|c|}{ Percent VAT $>$ Predicted } \\
\hline & (1) & (2) & $(3)$ & $(4)$ & $(5)$ \\
\hline Deterrence Letter X final sales share & $\begin{array}{c}1.51^{* * *} \\
(0.23)\end{array}$ & & & $\begin{array}{c}1.51^{* * * *} \\
(0.25)\end{array}$ & $\begin{array}{c}1.44^{* * *} \\
(0.24)\end{array}$ \\
\hline Deterrence Letter X size category & & $\begin{array}{c}-0.10^{* * *} \\
(0.03)\end{array}$ & & $\begin{array}{l}-0.03 \\
(0.04)\end{array}$ & \\
\hline Deterrence Letter X log employees & & & $\begin{array}{c}-0.28^{* * *} \\
(0.10)\end{array}$ & & $\begin{array}{l}-0.11 \\
(0.11)\end{array}$ \\
\hline Deterrence Letter & $\begin{array}{c}0.74^{* * *} \\
(0.14)\end{array}$ & $\begin{array}{c}2.15^{* * *} \\
(0.26)\end{array}$ & $\begin{array}{c}1.57^{* * *} \\
(0.12)\end{array}$ & $\begin{array}{c}1.00^{* * *} \\
(0.32)\end{array}$ & $\begin{array}{c}0.83^{* * *} \\
(0.16)\end{array}$ \\
\hline Constant & $\begin{array}{c}48.48^{* * *} \\
(0.08)\end{array}$ & $\begin{array}{c}49.79^{* * *} \\
(0.08)\end{array}$ & $\begin{array}{c}48.26^{* * *} \\
(0.08)\end{array}$ & $\begin{array}{c}50.01^{* * *} \\
(0.08)\end{array}$ & $\begin{array}{c}48.48^{* * *} \\
(0.08)\end{array}$ \\
\hline Final sales share $\mathrm{X}$ post & Yes & No & No & Yes & Yes \\
\hline Size measure $\mathrm{X}$ post & No & Yes & Yes & Yes & Yes \\
\hline Firm fixed effects & Yes & Yes & Yes & Yes & Yes \\
\hline Month fixed effects & Yes & Yes & Yes & Yes & Yes \\
\hline Observations & $7,308,631$ & $7,116,590$ & $7,340,994$ & $7,084,823$ & $7,308,631$ \\
\hline Number of Firms & 406,834 & 396,135 & 408,636 & 394,367 & 406,834 \\
\hline Adjusted $R^{2}$ & 0.28 & 0.26 & 0.29 & 0.26 & 0.28 \\
\hline
\end{tabular}

Notes: Regression of the probability of monthly VAT declared being higher than in the same month the previous year (Panel A) and on being higher than predicted (Panel B). Coefficients and standard errors are multiplied by 100 to express effects in percent. Sample includes all firms in the deterrence treatment and in the control group. Number of observations vary due to missing observations for some variables. Final sales share is not defined for firms with zero sales in preceding year, size category is not available for new firms. Robust standard errors in parentheses, clustered at the firm level. ${ }^{* * *} \mathrm{p}<0.01,{ }^{* *} \mathrm{p}<0.05,{ }^{*} \mathrm{p}<0.1$. 
Table 8: Spillover Effects on Trading Partners' VAT Payments

\begin{tabular}{|c|c|c|c|c|c|c|}
\hline & $\begin{array}{c}(1) \\
\text { Percent VAT } \\
>\text { Previous } \\
\text { Year }\end{array}$ & $\begin{array}{c}(2) \\
\text { Percent } \\
\text { VAT > } \\
\text { Predicted }\end{array}$ & $\begin{array}{c}(3) \\
\text { Percent VAT } \\
>\text { Previous } \\
\text { Year }\end{array}$ & $\begin{array}{c}(4) \\
\text { Percent } \\
\text { VAT > } \\
\text { Predicted }\end{array}$ & $\begin{array}{c}(5) \\
\text { Percent VAT } \\
>\text { Previous } \\
\text { Year }\end{array}$ & $\begin{array}{c}(6) \\
\text { Percent } \\
\text { VAT > } \\
\text { Predicted }\end{array}$ \\
\hline $\begin{array}{l}\text { Audit announcement X } \\
\text { post }\end{array}$ & $\begin{array}{c}2.50^{* *} \\
(1.15)\end{array}$ & $\begin{array}{l}2.08^{*} \\
(1.12)\end{array}$ & & & & \\
\hline $\begin{array}{l}\text { Audit announcement X } \\
\text { supplier X post }\end{array}$ & & & $\begin{array}{c}4.57^{* * *} \\
(1.56)\end{array}$ & $\begin{array}{c}4.06^{* * *} \\
(1.51)\end{array}$ & $\begin{array}{c}4.43^{* * *} \\
(1.53)\end{array}$ & $\begin{array}{c}3.96^{* * *} \\
(1.53)\end{array}$ \\
\hline $\begin{array}{l}\text { Audit announcement } \mathrm{X} \\
\text { client X post }\end{array}$ & & & $\begin{array}{l}-0.26 \\
(1.66)\end{array}$ & $\begin{array}{l}-0.26 \\
(1.52)\end{array}$ & $\begin{array}{l}-0.13 \\
(1.69)\end{array}$ & $\begin{array}{l}-0.25 \\
(1.56)\end{array}$ \\
\hline Supplier X post & & & $\begin{array}{l}-0.71 \\
(1.62)\end{array}$ & $\begin{array}{c}0.34 \\
(1.58)\end{array}$ & $\begin{array}{l}-1.19 \\
(1.66)\end{array}$ & $\begin{array}{c}0.61 \\
(1.64)\end{array}$ \\
\hline Constant & $\begin{array}{c}52.07 * * * \\
(0.95)\end{array}$ & $\begin{array}{c}49.06^{* * *} \\
(0.94)\end{array}$ & $\begin{array}{c}52.07^{* * *} \\
(0.95)\end{array}$ & $\begin{array}{c}49.06^{* * *} \\
(0.94)\end{array}$ & $\begin{array}{c}52.75^{* * *} \\
(0.96)\end{array}$ & $\begin{array}{c}50.11^{* * *} \\
(0.96)\end{array}$ \\
\hline $\begin{array}{l}\text { Controls X post } \\
\text { Controls X }\end{array}$ & No & No & No & No & Yes & Yes \\
\hline audit announcement $\mathrm{X}$ post & No & No & No & No & Yes & Yes \\
\hline Month fixed effects & Yes & Yes & Yes & Yes & Yes & Yes \\
\hline Firm fixed effects & Yes & Yes & Yes & Yes & Yes & Yes \\
\hline Number of observations & 45,264 & 45,264 & 45,264 & 45,264 & 44,288 & 44,288 \\
\hline Number of firms & 2,829 & 2,829 & 2,829 & 2,829 & 2,768 & 2,768 \\
\hline Adjusted $R^{2}$ & 0.05 & 0.11 & 0.05 & 0.11 & 0.05 & 0.10 \\
\hline
\end{tabular}

Notes: Regressions for trading partners of audited firms. Column (1), (3) and (5) shows the probability of an increase in declared VAT since the previous year, Column (2), (4) and (6) shows the probability of declaring more than predicted. The controls in Columns (4) and (6) are firm sales, sales/input-ratio, share of sales going to final consumers, and industry categorized as "hard-to-monitor." Time period includes six months after mailing of the audit announcements. Coefficients and standard errors are multiplied by 100 to express effects in percent. Robust standard errors in parentheses, clustered at the level of the audited firm. ${ }^{* * *} \mathrm{p}<0.01,{ }^{* *} \mathrm{p}<0.05,{ }^{*} \mathrm{p}<0.1$. 


\section{A Letter Templates (Translated from Spanish)}

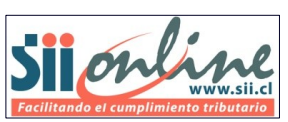

Santiago, November 19th 2008.

$\operatorname{Mr}(\mathrm{s}) . \mathrm{Abc}$

Business XYZ

210 Example Street

Concepción

Ref: SII informs about analysis of your company

Mr. (s) Taxpayer:

This is an informational letter and, therefore, does not require that you take any action vis-àvis the SII.

We would like to inform you that in a process of random selection process among the micro, small and medium size enterprises (MSMEs), YOUR FIRM HAS BEEN SELECTED FOR ANALYSIS. In the event that any irregularities are detected, you could be summond for an audit.

Our intention is to inform you of the usual actions that the SII carries out, and at the same time to remind you to always declare all purchases, sales and services, and deduct only the credits to which you are entitled.

We emphasize that this letter DOES NOT REQUIRE ANY PROCEEDINGS with the SII, and therefore YOU DO NOT NEED TO VISIT our offices.

On the SII Web site www.sii.cl, you may select the option "Contact Us" to ask questions or make suggestions, or you may call our Help Desk, telephone numbers 2-395 11 15, for clarification regarding the use of electronic tax services.

Yours sincerely,

Internal Revenue Service

Figure A1: Deterrence Letter 
Mr. (s)

Business XYZ

210 Example Street

Concepción

\section{Did you know that Chile has one of the highest levels of tax compliance in the world?}

Dear Taxpayer:

We wish to inform you that $98.3 \%$ of the taxes in our country are paid on a voluntary basis. This has allowed Chile to have one of the highest levels of tax compliance worldwide, according to information from the Organization for Economic Cooperation and Development (OECD).

This success is a result of the fact that the majority of Chileans declare and pay taxes in accordance with the provisions of the law.

We invite you to continue on this path and together achieve the country we all want, a Chile with more and more integrity, solidarity and development.

Yours sincerely,

Internal Revenue Service

Figure A2: Tax Morale Letter 


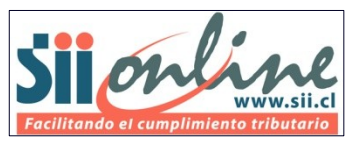

Santiago, November $19^{\text {th }} 2008$.

$\operatorname{Mr}(\mathrm{s}) \mathrm{Abc}$

Business XYZ

210 Example Street

Concepción

Ref: Visit the Web site of the Internal Revenue Service (www.sii.cl)

Dear Taxpayer:

We want to tell you that the SII Virtual Office now has an option called "Electronic Tax Folder", a tool that allows taxpayers to bring together in a single electronic document, statements and tax information that they are required to submit to banks or other institutions.

For more information, you can visit the SII Virtual Office website (www.sii.cl), menu "Tax Status", option "Electronic Tax Folder".

In our Virtual Office you will also find online deals, news, economic indicators, tax information, FAQs and guidelines for most of your dealings with the SII, such as tax returns, changes in information and payment of contributions.

Take advantage of the internet: visit www.sii.cl.

Yours sincerely,

Internal Revenue Service

Figure A3: Placebo Letter 


\section{Silionline}

Santiago, November 19th 2008.

Mr. (s)

Business XYZ

210 Example Street

Concepción

\section{Ref: Information about the SII future audit process.}

Dear Taxpayer:

This is an informational letter and, therefore, does not require that you take any action vis-àvis the SII.

We wish to inform you that according to control policies carried out by our institution, and under Law 18,320, YOU WILL RECEIVE A NOTIFICATION THAT YOU WILL BE AUDITED AT SOME POINT BETWEEN JUNE AND AUGUST 2009.

The purpose of this letter is to give you time to prepare your records for future audit. Later, you can expect a FORMAL NOTIFICATION LETTER, which will inform you which SII office you need to attend, what documents you need to bring and the date of the audit.

As such, YOU SHOULD NOT APPROACH THE SII OFFICES before receiving the formal notification letter.

Also, remember that you can declare, correct or amend your earlier statements in the SII Virtual Office on the internet (www.sii.cl).

Yours sincerely,

Internal Revenue Service

Figure A4: Pre-Announcement Letter 


\section{B Additional Figures}

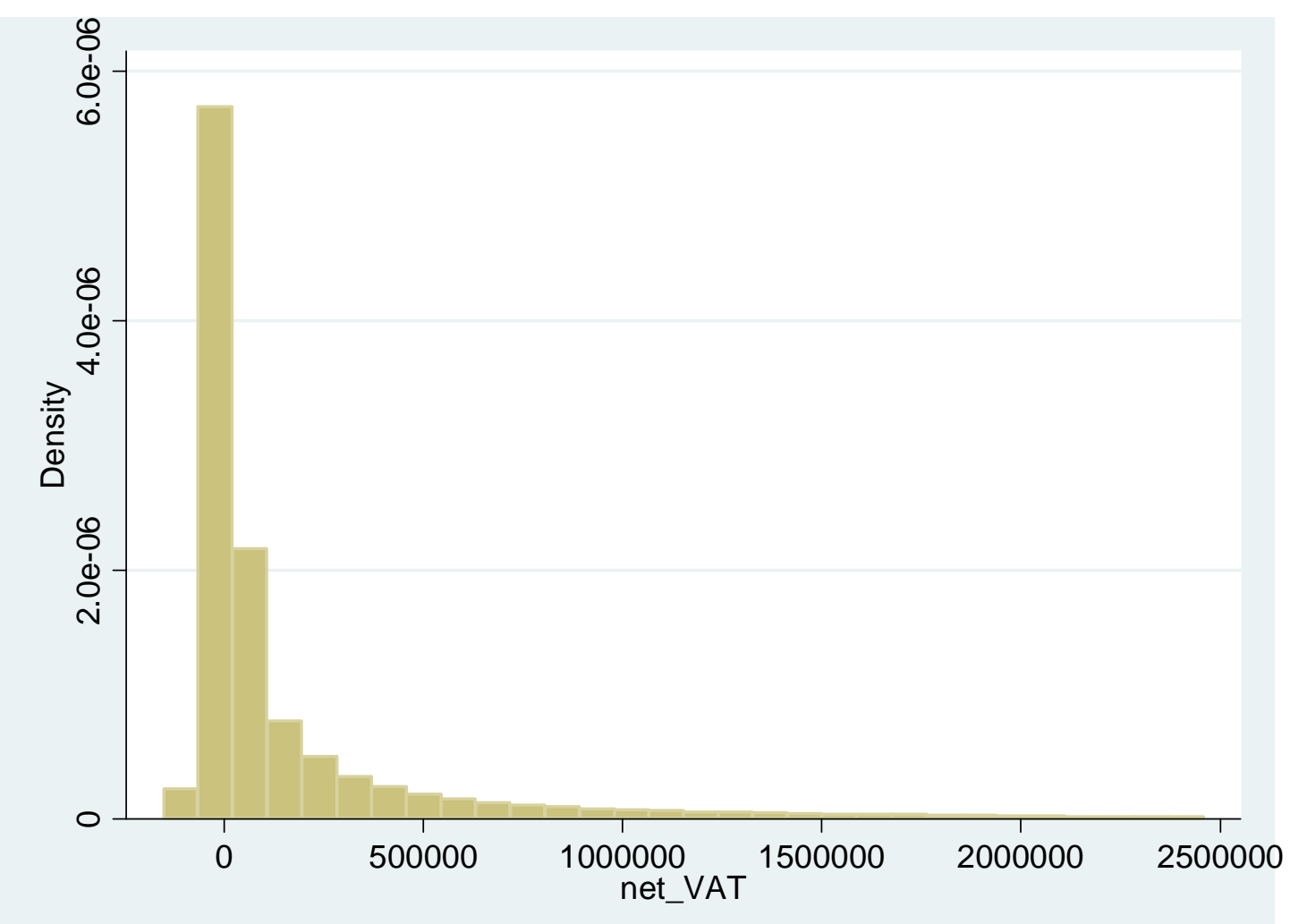

Figure A5: Distribution of monthly declared VAT excluding the top and bottom 5\% 


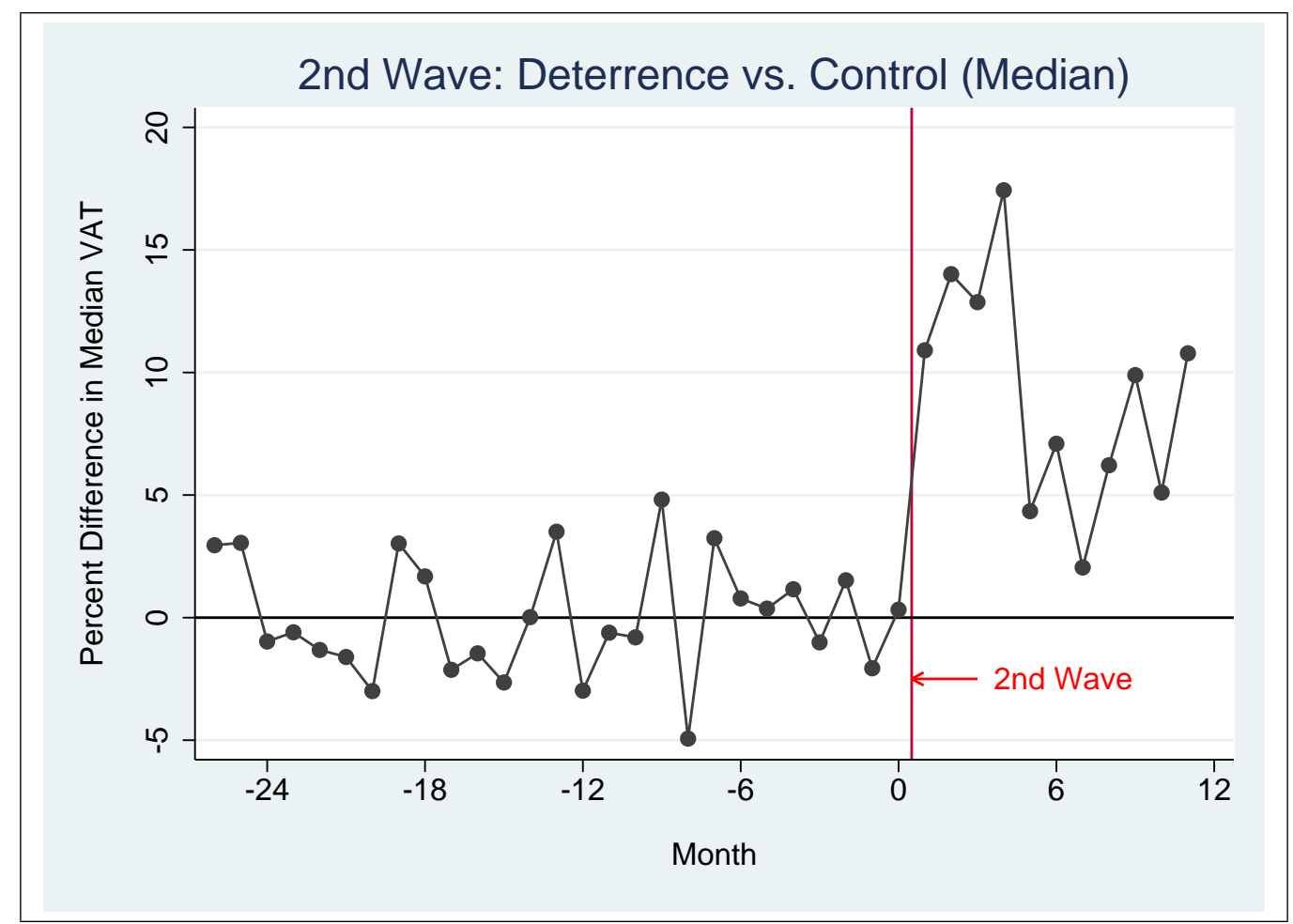

Figure A6: Impact of Deterrence Letter: Second Wave of Mailing

Notes: This figure plots the monthly percent difference between the medians of the treatment and the control group of the deterrence letter for the second wave of mailing: (median VAT treatment group - median VAT control group) / (median VAT control group), normalizing pre-treatment percent difference to zero. The y-axis indicates time, with monthly observations, and zero indicates the last month before the mailing of the letters. The vertical line marks mailing of the letters. Since the second wave of mailing is much smaller than the first, the figure shows a more noisy pattern than the first wave displayed in Figure 1, Panel A. 


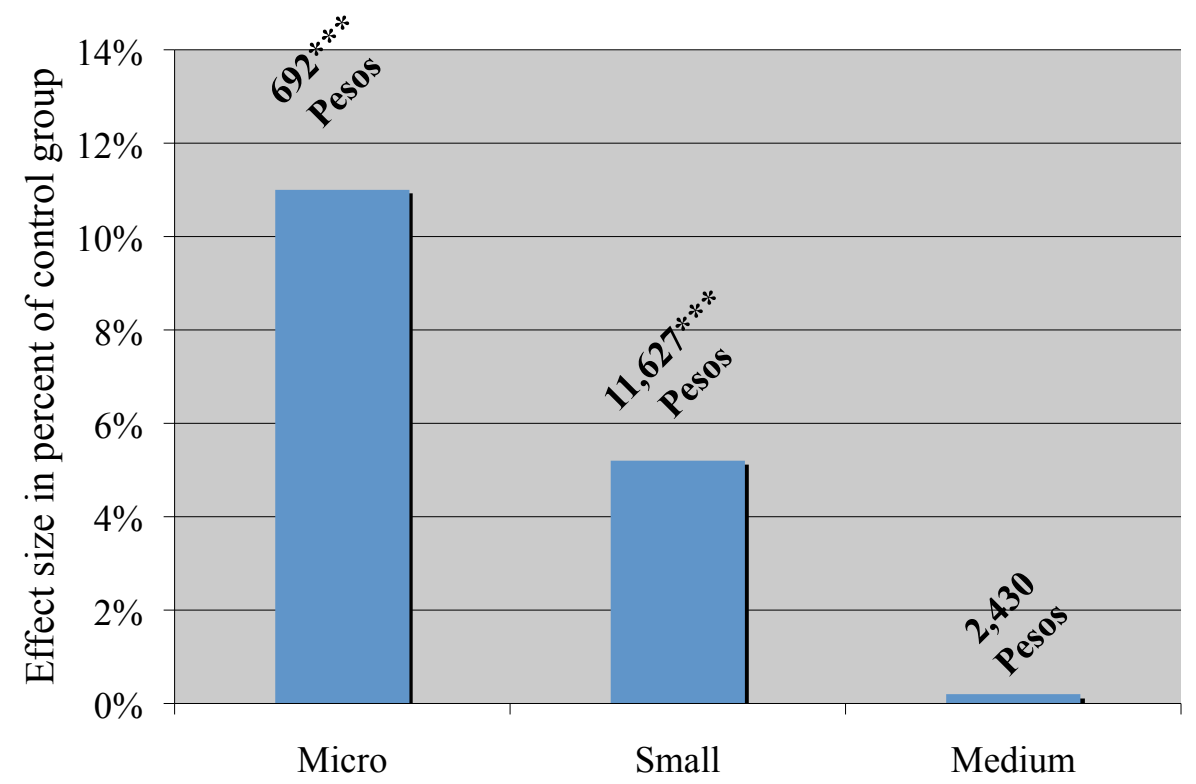

Figure A7: Impact by Firm Size (Median Regression)

Notes: Each bar represents a separate median regression for each size category. The numbers on top of the bars indicate the coefficient on being in the deterrence letter treatment group of a median regression of mean monthly VAT payments in the four months following treatment. The height of the bar indicates the effect in percent relative to the mean in the control group in that size category. ${ }^{* * *}=\mathrm{p}<0.01,{ }^{* *}=\mathrm{p}<0.05,{ }^{*}=$ $\mathrm{p}<0.1$ 


\section{Additional Tables}

\section{Dynamics over Time}

Table A1: Deterrence Letter Experiment: Monthly Effects on VAT Payments

\begin{tabular}{|c|c|c|c|}
\hline & $\begin{array}{c}(1) \\
\text { Percent VAT }>\text { Previous Year }\end{array}$ & $\begin{array}{c}(2) \\
\text { Percent VAT > Predicted }\end{array}$ & $\begin{array}{c}(3) \\
\text { Percent VAT > Zero }\end{array}$ \\
\hline Deterrence X t-5 & $\begin{array}{l}-0.02 \\
(0.17)\end{array}$ & $\begin{array}{l}-0.12 \\
(0.18)\end{array}$ & $\begin{array}{l}-0.07 \\
(0.17)\end{array}$ \\
\hline Deterrence X t-4 & $\begin{array}{c}0.26 \\
(0.17)\end{array}$ & $\begin{array}{c}0.03 \\
(0.18)\end{array}$ & $\begin{array}{c}0.02 \\
(0.17)\end{array}$ \\
\hline Deterrence $\mathrm{X} \mathrm{t}$ t-3 & $\begin{array}{c}0.10 \\
(0.17)\end{array}$ & $\begin{array}{l}-0.29^{*} \\
(0.18)\end{array}$ & $\begin{array}{l}-0.03 \\
(0.17)\end{array}$ \\
\hline Deterrence X t-2 & $\begin{array}{c}0.05 \\
(0.17)\end{array}$ & $\begin{array}{l}-0.30^{*} \\
(0.18)\end{array}$ & $\begin{array}{l}-0.14 \\
(0.17)\end{array}$ \\
\hline Deterrence X t-1 & $\begin{array}{c}0.19 \\
(0.17)\end{array}$ & $\begin{array}{l}-0.07 \\
(0.18)\end{array}$ & $\begin{array}{l}-0.09 \\
(0.17)\end{array}$ \\
\hline Deterrence $\mathrm{X} \mathrm{t} 1$ & $\begin{array}{c}1.07^{* * *} \\
(0.17)\end{array}$ & $\begin{array}{c}1.17^{* * *} \\
(0.18)\end{array}$ & $\begin{array}{c}0.48^{* * *} \\
(0.17)\end{array}$ \\
\hline Deterrence X t2 & $\begin{array}{c}1.76^{* * *} \\
(0.17)\end{array}$ & $\begin{array}{c}1.73^{* * *} \\
(0.18)\end{array}$ & $\begin{array}{c}0.56^{* * *} \\
(0.17)\end{array}$ \\
\hline Deterrence $\mathrm{X}$ t3 & $\begin{array}{c}1.46^{* * *} \\
(0.17)\end{array}$ & $\begin{array}{c}1.30^{* * *} \\
(0.18)\end{array}$ & $\begin{array}{c}0.48^{* * *} \\
(0.17)\end{array}$ \\
\hline Deterrence X t4 & $\begin{array}{c}1.64^{* * *} \\
(0.17)\end{array}$ & $\begin{array}{c}1.21^{* * *} \\
(0.18)\end{array}$ & $\begin{array}{c}0.46^{* * *} \\
(0.17)\end{array}$ \\
\hline Deterrence X t5 & $\begin{array}{c}0.99^{* * *} \\
(0.17)\end{array}$ & $\begin{array}{c}0.83^{* * *} \\
(0.18)\end{array}$ & $\begin{array}{l}-0.15 \\
(0.17)\end{array}$ \\
\hline Deterrence $\mathrm{X} \mathrm{t6}$ & $\begin{array}{c}0.94^{* * *} \\
(0.17)\end{array}$ & $\begin{array}{c}0.72^{* * *} \\
(0.18)\end{array}$ & $\begin{array}{c}0.12 \\
(0.17)\end{array}$ \\
\hline Deterrence $\mathrm{X}$ t7 & $\begin{array}{c}0.88^{* * *} \\
(0.17)\end{array}$ & $\begin{array}{c}0.59^{* * *} \\
(0.18)\end{array}$ & $\begin{array}{l}0.04 \\
(0.17)\end{array}$ \\
\hline Deterrence $\mathrm{X} \mathrm{t} 8$ & $\begin{array}{c}0.92^{* * *} \\
(0.19)\end{array}$ & $\begin{array}{c}0.63^{* * *} \\
(0.20)\end{array}$ & $\begin{array}{c}0.17 \\
(0.20)\end{array}$ \\
\hline Deterrence X t9 & $\begin{array}{c}0.85^{* * *} \\
(0.19)\end{array}$ & $\begin{array}{c}0.75^{* * *} \\
(0.20)\end{array}$ & $\begin{array}{c}0.31 \\
(0.20)\end{array}$ \\
\hline Deterrence X t10 & $\begin{array}{c}0.87^{* * *} \\
(0.19)\end{array}$ & $\begin{array}{c}0.68^{* * *} \\
(0.20)\end{array}$ & $\begin{array}{c}0.10 \\
(0.20)\end{array}$ \\
\hline Deterrence X t11 & $\begin{array}{c}0.73^{* * *} \\
(0.19)\end{array}$ & $\begin{array}{c}0.82^{* * *} \\
(0.20)\end{array}$ & $\begin{array}{c}0.16 \\
(0.20)\end{array}$ \\
\hline Deterrence X t12 & $\begin{array}{c}0.77^{* * *} \\
(0.19)\end{array}$ & $\begin{array}{c}0.51^{* * *} \\
(0.20)\end{array}$ & $\begin{array}{c}0.12 \\
(0.20)\end{array}$ \\
\hline Constant & $\begin{array}{c}47.00^{* * *} \\
(0.09)\end{array}$ & $\begin{array}{c}48.26^{* * *} \\
(0.09)\end{array}$ & $\begin{array}{c}65.31^{* * *} \\
(0.09)\end{array}$ \\
\hline Month fixed effects & Yes & Yes & Yes \\
\hline Number of obs. & $6,859,747$ & $6,859,747$ & $6,859,747$ \\
\hline $\begin{array}{l}\text { Number of firms } \\
R^{2}\end{array}$ & $\begin{array}{c}408,636 \\
0.004\end{array}$ & $\begin{array}{c}408,636 \\
0.000\end{array}$ & $\begin{array}{c}408,636 \\
0.005\end{array}$ \\
\hline
\end{tabular}

Notes: Each column shows a linear probability regression on interaction terms of being assigned to receive a deterrence letter with month dummies. Coefficients and standard errors are multiplied by 100 to express effects in percent. Sample includes all firms in the deterrence treatment and the control group. Robust standard errors in parentheses, clustered at the firm level. ${ }^{* * *} \mathrm{p}<0.01,{ }^{* *} \mathrm{p}<0.05,{ }^{*} \mathrm{p}<0.1$. 


\section{Alternate Sample for Table 5}

Table A2: Impact of Deterrence Letter on Different Types of Transaction

Sample Including Pure Retailers and Intermediary Firms

\begin{tabular}{|c|c|c|c|c|}
\hline & $\begin{array}{c}(1) \\
\text { Percent Sales }> \\
\text { Previous Year }\end{array}$ & $\begin{array}{c}(2) \\
\text { Percent Input Costs }> \\
\text { Previous Year } \\
\end{array}$ & $\begin{array}{c}(3) \\
\text { Percent Intermediary } \\
\text { Sales }>\text { Previous Year }\end{array}$ & $\begin{array}{c}(4) \\
\text { Percent Final Sales }> \\
\text { Previous Year }\end{array}$ \\
\hline Deterrence & $\begin{array}{c}1.01^{* * *} \\
(0.12)\end{array}$ & $\begin{array}{l}-0.02 \\
(0.12)\end{array}$ & $\begin{array}{c}0.22^{* *} \\
(0.10)\end{array}$ & $\begin{array}{c}0.90^{* * *} \\
(0.10)\end{array}$ \\
\hline Constant & $\begin{array}{c}50.07^{* * *} \\
(0.07)\end{array}$ & $\begin{array}{c}48.94^{* * *} \\
(0.07)\end{array}$ & $\begin{array}{c}29.40^{* * * *} \\
(0.06)\end{array}$ & $\begin{array}{c}29.03^{* * *} \\
(0.06)\end{array}$ \\
\hline Month fixed effects & Yes & Yes & Yes & Yes \\
\hline Number of observations & $7,340,994$ & $7,340,994$ & $7,340,994$ & $7,340,994$ \\
\hline Number of firms & 408,636 & 408,636 & 408,636 & 408,636 \\
\hline Adjusted $R^{2}$ & 0.28 & 0.25 & 0.38 & 0.47 \\
\hline
\end{tabular}

Notes: Regressions of the probability of the line item (total sales, total input costs, intermediary sales, and final sales) being higher than in the same month the previous year, among the full sample including pure retailers and intermediary firms. Coefficients and standard errors are multiplied by 100 to express effects in percent. Sample includes all firms in the deterrence treatment and the control group. Robust standard errors in parentheses, clustered at the firm level. ${ }^{* * *} \mathrm{p}<0.01,{ }^{* *} \mathrm{p}<0.05,{ }^{*} \mathrm{p}<0.1$. 


\section{Research Design Diagrams}

\section{Letter Message Experiment}

\begin{tabular}{|l|l|l|}
\hline $\begin{array}{l}\text { Deterrence } \\
\text { message } \\
\text { Indicating increased } \\
\text { audit probability } \\
\text { (N=102'031 firms) }\end{array}$ & $\begin{array}{l}\text { Tax morale message } \\
\text { Information about } \\
\text { social norm } \\
(\mathrm{N}=18 ' 579 \text { firms })\end{array}$ & $\begin{array}{l}\text { Placebo message } \\
\text { Information about } \\
\text { website } \\
(\mathrm{N}=18 ' 519 \text { firms })\end{array}$ \\
\hline
\end{tabular}

\begin{tabular}{|l|}
\hline Control group \\
No letter \\
$\mathrm{N}=306,605)$ \\
\end{tabular}

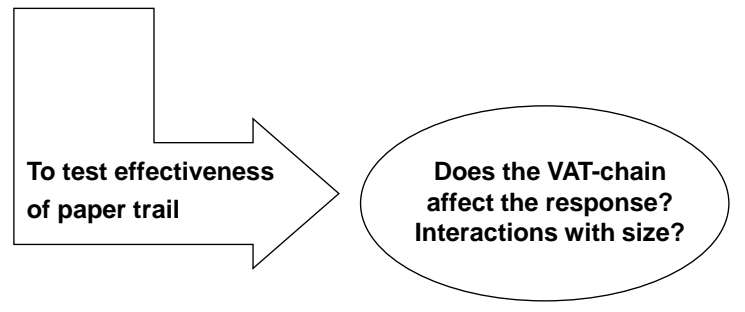

$\underline{\text { Spillover Experiment }}$

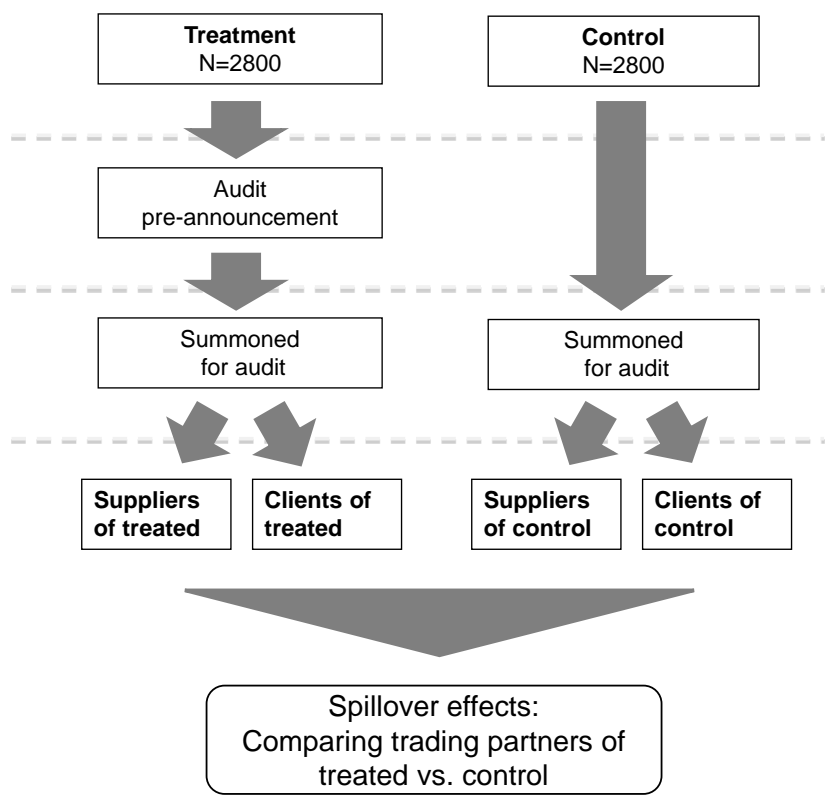

Figure A8 